\title{
Ecto-5'-Nucleotidase (CD73)-Mediated Formation of Adenosine Is Critical for the Striatal Adenosine $\mathrm{A}_{2 \mathrm{~A}}$ Receptor Functions
}

\author{
Elisabete Augusto, ${ }^{1,2,3}$ Marco Matos, ${ }^{1,2,3}$ Jean Sévigny, ${ }^{4,5}$ Ali El-Tayeb, ${ }^{6}$ Margaret S. Bynoe, ${ }^{7}$ Christa E. Müller, ${ }^{6}$ \\ Rodrigo A. Cunha, ${ }^{2,3}$ and Jiang-Fan Chen ${ }^{1}$ \\ ${ }^{1}$ Department of Neurology, Boston University, School of Medicine, Boston, Massachusetts 02118, ${ }^{2} \mathrm{CNC}$-Centre for Neuroscience and Cell Biology and \\ ${ }^{3}$ Faculty of Medicine, University of Coimbra, 3004-517 Coimbra, Portugal, ${ }^{4}$ Centre de Recherche en Rhumatologie et Immunologie, Centre Hospitalier \\ Universitaire de Québec, Québec City, Québec G1R 2J6, Canada, ${ }^{5}$ Département de Microbiologie-Infectiologie et d'Immunologie, Faculté de Médecine, \\ Université Laval, Québec City, Québec G1V 0A6, Canada, ${ }^{6}$ Pharma-Zentrum Bonn, Pharmazeutisches Institut, Pharmazeutische Chemie I, University of \\ Bonn, D-53121 Bonn, Germany, and 7Department of Microbiology and Immunology, College of Veterinary Medicine, Cornell University, Ithaca, New York 14853
}

Adenosine is a neuromodulator acting through inhibitory $A_{1}$ receptors $\left(A_{1} R s\right)$ and facilitatory $A_{2 A}$ Rs, which have similar affinities for adenosine. It has been shown that the activity of intracellular adenosine kinase preferentially controls the activation of $A_{1} R s$, but the source of the adenosine activating $\mathrm{A}_{2 \mathrm{~A}}$ Rs is unknown. We now show that ecto-5' -nucleotidase (CD73), the major enzyme able to convert extracellular AMP into adenosine, colocalizes with $\mathrm{A}_{2 \mathrm{~A}} \mathrm{Rs}$ in the basal ganglia. In addition to astrocytes, striatal CD73 is prominently localized to postsynaptic sites. Notably, CD73 coimmunoprecipitated with $\mathrm{A}_{2 \mathrm{~A}} \mathrm{Rs}$ and proximity ligation assays confirmed the close proximity of $\mathrm{CD} 73$ and $\mathrm{A}_{2 \mathrm{~A}} \mathrm{Rs}$ in the striatum. Accordingly, the cAMP formation in synaptosomes as well as the hypolocomotion induced by a novel $\mathrm{A}_{2 \mathrm{~A}} \mathrm{R}$ prodrug that requires $\mathrm{CD} 73$ metabolization to activate $\mathrm{A}_{2 \mathrm{~A}}$ Rs were observed in wild-type mice, but not in CD73 knock-out (KO) mice or $\mathrm{A}_{2 \mathrm{~A}} \mathrm{R}$ KO mice. Moreover, $\mathrm{CD} 73 \mathrm{KO}$ mice displayed increased working memory performance and a blunted amphetamineinduced sensitization, mimicking the phenotype of global or forebrain- $A_{2 A} R$ KO mice, as well as upon pharmacological $A_{2 A} R$ blockade. These results show that CD73-mediated formation of extracellular adenosine is responsible for the activation of striatal $A_{2 A} R$ function. This study points to CD73 as a new target that can fine-tune $A_{2 A} R$ activity, and a novel therapeutic target to manipulate $A_{2 A} R-m e d i a t e d$ control of striatal function and neurodegeneration.

\section{Introduction}

Adenosine is a neuromodulator that fine-tunes brain neurotransmission mainly acting through inhibitory $A_{1}$ receptors $\left(A_{1} R s\right)$ and facilitatory $A_{2 A}$ Rs (Fredholm et al., 2005). $A_{1}$ Rs are abundantly expressed throughout the brain, controlling synaptic transmission (Dunwiddie and Masino, 2001). $\mathrm{A}_{1} \mathrm{R}$ activation depends on the tissue workload (Cunha, 2001a), and adenosine kinase activity is a key regulator of endogenous adenosine activating $A_{1} R s$ (Boison, 2011). In accordance with their inhibitory role curtailing excitatory transmission, bolstering $A_{1} R$ activation

Received Dec. 17, 2012; revised April 11, 2013; accepted May 14, 2013.

Author contributions: E.A., R.A.C., and J.-F.C. designed research; E.A. and M.M. performed research; J.S., A.E.-T., M.S.B., and C.E.M. contributed unpublished reagents/analytic tools; E.A., R.A.C., and J.-F.C. analyzed data; E.A., M.M., J.S., C.E.M., R.A.C., and J.-F.C. wrote the paper.

This research was supported by Fundação para a Ciência e a Tecnologia (FCT; Grant SAU-TOX/122005/2010) and Defense Advanced Research Projects Agency (Grant 09-68-ESR-FP-010), and PhD fellowships from FCT (SFRH/BD/ 47824/2008 to E.A. and FRH/BD/36289/2007 to M.M.), a "Chercheur Boursier Senior" grant from Le Fond de Recherche du Québec-Santé (to J.S.), National Institutes of Health Grant NS041083-11 and NS073947, and the Cogan Foundation (J.F.C.).

Correspondence should be addressed to either of the following: Rodrigo A. Cunha, CNC-Centre for Neuroscience and Cell Biology, University of Coimbra, 3004-517 Coimbra, Portugal, E-mail: cunharod@gmail.com; or Jiang-Fan Chen, Department of Neurology, Boston University, School of Medicine, Boston, MA 02118, E-mail: chenj@@bu.edu.

A. El-Tayeb's present address: Faculty of Pharmacy, Al-Azhar University, Assiut, Egypt.

DOI:10.1523/JNEUROSCI.5817-12.2013

Copyright $\odot 2013$ the authors $\quad 0270-6474 / 13 / 3311390-10 \$ 15.00 / 0$ through inhibition of adenosine kinase affords neuroprotection against brain damage involving glutamate excitotoxicity (Fredholm et al., 2005), namely upon epilepsy and brain ischemia (Boison, 2006). Importantly, the manipulation of the metabolic pathways associated with $A_{1} R$ activation is more promising than the direct $A_{1} R$ activation to control neurodegeneration, since the former locally enhances adenosine where activity is disrupted, whereas the latter also activates peripheral $A_{1} R$ causing marked cardiovascular effects (Cunha, 2005).

The brain distribution of $\mathrm{A}_{2 \mathrm{~A}}$ Rs is different from that of $\mathrm{A}_{1} \mathrm{Rs}$ : $\mathrm{A}_{2 \mathrm{~A}}$ Rs are most abundant in the basal ganglia (Schiffmann et al., 1991), but are also present at lower density throughout the brain (Rosin et al., 2003). Like $A_{1}$ Rs, $A_{2 A}$ Rs are mostly located at synapses (Rebola et al., 2003, 2005), but they fulfill different roles. Thus, $\mathrm{A}_{2 \mathrm{~A}}$ Rs are selectively engaged to assist the implementation of synaptic plastic changes in excitatory synapses (Cunha, 2008), by facilitating NMDA receptor-mediated responses (Rebola et al., 2008), by increasing glutamate release (Rodrigues et al., 2005), and by desensitizing presynaptic inhibitory modulation of systems like $A_{1}$ Rs (Lopes et al., 2002; Ciruela et al., 2006) or cannabinoid $\mathrm{CB}_{1}$ Rs (Martire et al., 2011). Therefore, $\mathrm{A}_{2 \mathrm{~A}}$ Rs play a key role in modulating the plasticity of neuronal circuits, such as upon learning and memory (Zhou et al., 2009; Wei et al., 2011) 
or drug addiction (Chen et al., 2003). Notably, neurodegenerative conditions are accompanied by an upregulation of $\mathrm{A}_{2 \mathrm{~A}} \mathrm{Rs}$ (Cunha, 2005), justifying that $\mathrm{A}_{2 \mathrm{~A}}$ R blockade controls the burden of Parkinson's (Chen et al., 2001) or Alzheimer's disease (Canas et al., 2009).

The source of the adenosine activating $\mathrm{A}_{2 \mathrm{~A}} \mathrm{Rs}$ is poorly characterized. We have previously shown that different sources of adenosine activate $A_{1}$ Rs and $A_{2 A}$ Rs (Cunha et al., $1996 \mathrm{a}$ ) and that $\mathrm{A}_{2 \mathrm{~A}} \mathrm{Rs}$ are selectively activated upon extracellular catabolism by ecto-nucleotidases of ATP (Cunha et al., 1996a; Rebola et al., 2008). We have also shown that the ATPderived formation of adenosine by ecto-nucleotidases is limited and controlled by ecto-5' -nucleotidase (CD73) activity (Cunha, 2001b), the only enzyme able to dephosphorylate extracellular AMP into adenosine in the brain (Lovatt et al., 2012). In agreement with this proposed functional association between CD73 and $\mathrm{A}_{2 \mathrm{~A}}$ Rs, CD73 activity displays a brain distribution similar to $\mathrm{A}_{2 \mathrm{~A}} \mathrm{Rs}$, both being higher in the basal ganglia (Langer et al., 2008).

Using mice deficient in either CD73 or $\mathrm{A}_{2 \mathrm{~A}} \mathrm{Rs}$, coupled with a novel $\mathrm{A}_{2 \mathrm{~A}} \mathrm{R}$ agonist prodrug requiring a CD73-mediated activation and a proximity ligation assay (PLA), we now explored whether $\mathrm{CD} 73$ and $\mathrm{A}_{2 \mathrm{~A}}$ Rs are colocalized and physically associated in the striatal neurons, and whether CD73 provides the particular pool of extracellular adenosine selectively responsible for activating striatal $\mathrm{A}_{2 \mathrm{~A}} \mathrm{Rs}$.

\section{Materials and Methods}

Animals. Approval from the Institutional Animal Care and Use Committee at Boston University School of Medicine and the Portuguese Veterinarian Office was granted for all experiments conducted in Boston and Coimbra, respectively. They adhered to the NIH Guide for the Care and Use of Laboratory Animals, the Portuguese Law and Ordinance on Animal Protection, and European Council Directive 86/609/EEC. The knock-out (KO) mice used, both with a C57BL/6 genetic background, were previously characterized, namely global-CD73 KO (CD73 KO) (Thompson et al., 2004), as well as the global- $\mathrm{A}_{2 \mathrm{~A}} \mathrm{R}$ KO mice $\left(\mathrm{A}_{2 \mathrm{~A}} \mathrm{R}\right.$ KO) (Chen et al., 1999). In all experiments, male and female adult (2-3 months old) mice were used.

Separation of total membranes. Mice were killed by decapitation after deep anesthesia with isoflurane, and the brain tissues were homogenized in sucrose $(0.32 \mathrm{M})$ solution containing $1 \mathrm{~mm}$ EDTA, 10 mM HEPES, 1 $\mathrm{mg} / \mathrm{ml}$ bovine serum albumin (BSA; Sigma), $\mathrm{pH} 7.4$ at $4^{\circ} \mathrm{C}$. The homogenates were centrifuged at $3000 \times g$ for $10 \mathrm{~min}$ at $4^{\circ} \mathrm{C}$, and the supernatants were then centrifuged at $14,000 \times g$ for $10 \mathrm{~min}$ at $4^{\circ} \mathrm{C}$. The pellets were washed in Krebs-HEPES-Ringer (KHR) solution containing 140 mM NaCl, 1 mm EDTA, 10 mm HEPES, $5 \mathrm{~mm} \mathrm{KCl}$, and 5 mm glucose, $\mathrm{pH}$ 7.4 at $4^{\circ} \mathrm{C}$, and were further centrifuged at $14,000 \times g$ for $10 \mathrm{~min}$ at $4^{\circ} \mathrm{C}$. The pellets were either resuspended in the incubation buffer for binding studies or in radioimmunoprecipitation assay (RIPA) buffer for Western blot analysis.

Purification of synaptosomes and gliosomes. After the homogenization of the brain tissue, synaptosomes and gliosomes were obtained using a discontinuous Percoll gradient $(2,6,15$, and $23 \% \mathrm{v} / \mathrm{v}$ of Percoll in a medium containing $0.32 \mathrm{M}$ sucrose and $1 \mathrm{~mm}$ EDTA, $\mathrm{pH}$ 7.4), as previously described (Matos et al., 2012a). The mixture was centrifuged at $31,000 \times g$ for $5 \mathrm{~min}$ at $4^{\circ} \mathrm{C}$ with braking speed set down to 0 after reaching $1500 \times g$ (Dunkley et al., 2008). The layers between $2 \%$ and $6 \%$ of Percoll (gliosomal fraction) and between $15 \%$ and $23 \%$ of Percoll (presynaptosomal fraction) were collected, washed in $10 \mathrm{ml}$ of HEPESbuffered medium containing $140 \mathrm{~mm} \mathrm{NaCl}, 5 \mathrm{~mm} \mathrm{KCl,} 5 \mathrm{~mm} \mathrm{NaHCO}$, $1.2 \mathrm{mM} \mathrm{NaH}_{2} \mathrm{PO}_{4}, 1 \mathrm{~mm} \mathrm{MgCl}, 10 \mathrm{~mm}$ glucose, and $10 \mathrm{~mm}$ HEPES, $\mathrm{pH}$ 7.4 , and further centrifuged at $22,000 \times g$ for $15 \mathrm{~min}$ at $4^{\circ} \mathrm{C}$ to remove myelin components and postsynaptic material from the gliosomal and synaptosomal fractions, respectively. Both fractions were resuspended in RIPA buffer for Western blot analysis.
Separation of presynaptic, postsynaptic, and extrasynaptic fractions. The separation of the presynaptic active zone, postsynaptic density and nonsynaptic fractions from nerve terminals was performed by combining solubilization steps and changes in $\mathrm{pH}$, as previously described (Rebola et al., 2005). Briefly, a solution with sucrose $(1.25 \mathrm{M})$ and $\mathrm{CaCl}_{2}(0.1 \mathrm{~mm})$ was gently added to the tissue homogenates under agitation. Another sucrose solution $(1 \mathrm{M})$ containing $0.1 \mathrm{mM} \mathrm{CaCl}_{2}$ was gently stratified over the homogenate, followed by centrifugation $\left(100,000 \times g\right.$ for $3 \mathrm{~h}$ at $\left.4^{\circ} \mathrm{C}\right)$ to separate nuclei and debris (pellet), myelin (top layer) and the synaptosomes (interface between 1.25 and $1 \mathrm{~m}$ of sucrose), which were diluted $1: 10$ in sucrose solution $(0.32 \mathrm{M})$ containing $0.1 \mathrm{mM} \mathrm{CaCl}_{2}, 1 \mathrm{mM} \mathrm{MgCl}_{2}$, $1 \mathrm{~mm}$ PMSF, and centrifuged $\left(15,000 \times g\right.$ for $30 \mathrm{~min}$ at $\left.4^{\circ} \mathrm{C}\right)$. The pellet (synaptosomes) was diluted $1: 10$ in cold $0.1 \mathrm{~mm} \mathrm{CaCl}_{2}$ and an equal volume of $2 \times$ solubilization buffer $(2 \%$ Triton X-100, $40 \mathrm{~mm}$ Tris, $\mathrm{pH}$ 6.0 ) was added to the suspension. The membranes were incubated for 30 min on ice with mild agitation, and the insoluble material (synaptic junctions) was pelleted $\left(40,000 \times g\right.$ for $30 \mathrm{~min}$ at $\left.4^{\circ} \mathrm{C}\right)$. The supernatant (extrasynaptic fraction) was decanted and proteins were precipitated with six volumes of acetone at $-20^{\circ} \mathrm{C}$ and recovered by centrifugation $\left(18,000 \times g\right.$ for $30 \mathrm{~min}$ at $\left.-15^{\circ} \mathrm{C}\right)$. The synaptic junctions pellet was washed in the solubilization buffer, $\mathrm{pH} 6.0$, and resuspended in 10 volumes of a second solubilization buffer (1\% Triton X-100, $20 \mathrm{~mm}$ Tris but at $\mathrm{pH}$ 8.0). This increase in $\mathrm{pH}$ allows the dissociation of the extracellular matrix that maintains the presynaptic active zone tightly bound to the postsynaptic density (Phillips et al., 2001). Hence, the active zone is solubilized, whereas the postsynaptic density is essentially preserved because the amount of detergent is not enough for its solubilization (Phillips et al., 2001). After incubation for $30 \mathrm{~min}$ on ice with mild agitation, the mixture was centrifuged and the supernatant (presynaptic fraction) processed as described for the extrasynaptic fraction, whereas the final insoluble pellet corresponds to the postsynaptic fraction. The samples were resuspended in RIPA buffer for Western blot analysis.

Co-immunoprecipitation. Co-immunoprecipitation (Co-IP) was performed as previously described (Ciruela et al., 2001). Briefly, total membranes from the striatum (1 mg) were prepared as described above, washed in PBS (140 mM NaCl, $3 \mathrm{~mm} \mathrm{KCl,} 20 \mathrm{~mm} \mathrm{Na} \mathrm{HPO}_{4}, 1.5 \mathrm{~mm}$ $\mathrm{KH}_{2} \mathrm{PO}_{4}$, pH 7.4), and centrifuged at $14,000 \times g$ for $10 \mathrm{~min}$ at $4^{\circ} \mathrm{C}$. The pellets were either resuspended in the immunoprecipitation buffer (IPB; containing $20 \mathrm{~mm}$ Tris, pH 7.0, $100 \mathrm{~mm} \mathrm{NaCl}, 2$ mm EDTA, 2 mM EGTA, $50 \mathrm{~mm} \mathrm{NaF}, 1 \mathrm{~mm}$ sodium orthovanadate, $1 \mu \mathrm{m}$ okadaic acid, $0.1 \mathrm{~mm}$ PMSF, and 1:1000 protease inhibitor cocktail) with $1 \%$ Triton X-100, sonicated for $30 \mathrm{~s}$ on ice, and further spun down for $10 \mathrm{~min}$ to remove insoluble materials. A sample was collected to determine the protein concentration using the bicinchoninic acid (BCA) assay (Thermo Scientific), another was stored at $-20^{\circ} \mathrm{C}$ as input (positive control), and the rest of the sample was processed for IP at a dilution of $0.5 \mathrm{mg} / \mathrm{ml}$. Protein A Sepharose beads were incubated with the sample for $1 \mathrm{~h}$ at $4^{\circ} \mathrm{C}$ under rotation to preabsorb any protein that nonspecifically binds to the protein A Sepharose beads. The supernatant was recovered by centrifugation and $3 \mu \mathrm{g}$ of anti- $\mathrm{A}_{2 \mathrm{~A}} \mathrm{R}$ antibody (Millipore) or irrelevant IgG (for negative control) was added and incubated for $3 \mathrm{~h}$ at $4^{\circ} \mathrm{C}$ under rotation. To pull down the immune complexes, samples were then incubated with protein A Sepharose beads for $2 \mathrm{~h}$ at $4^{\circ} \mathrm{C}$ and centrifuged. The pellets were washed twice in IPB with $1 \%$ Triton X-100, 3 times in IPB with $1 \%$ Triton $\mathrm{X}-100$ and $500 \mathrm{~mm} \mathrm{NaCl}$, and twice in IPB. The input (5\% of the initial sample), $20 \%$ of the supernatant of both pulldowns, as well as $100 \%$ of the immunoprecipitates were resolved in RIPA buffer, and Western blots were performed with anti- $\mathrm{A}_{2 \mathrm{~A}} \mathrm{R}$ or anti-CD73 antibodies (see Western blot).

Western blot. Western blotting was performed as previously described (Rebola et al., 2005), using nonreducing conditions for rabbit antimurine CD73. Incubation with the primary antibodies, namely rabbit anti-GFAP (1:20,000, Dakocytomation), mouse anti-synaptophysin (1: 50,000 , Sigma), mouse anti-syntaxin $(1: 50,000$, Sigma), mouse antiPSD-95 (1:100,000, Sigma), mouse anti- $\beta$-actin (1:20,000, Sigma), mouse anti- $\mathrm{A}_{2 \mathrm{~A}} \mathrm{R}$ (1:1000, Millipore), and rabbit anti-murine CD73 (1: 1000, Fausther et al., 2012), all diluted in Tris-buffered saline (137 mM $\mathrm{NaCl}$ and $20 \mathrm{~mm}$ Tris- $\mathrm{HCl}, \mathrm{pH} 7.6$ ) with $0.1 \%$ Tween (TBS-T) and $5 \%$ BSA (fatty acid free), was performed overnight at $4^{\circ} \mathrm{C}$. After washing 
twice with TBS-T, the membranes were incubated with appropriate IgG secondary antibodies conjugated with alkaline phosphatase (GE Healthcare) for $2 \mathrm{~h}$ at room temperature. After washing, the membranes were revealed using an ECF kit (GE Healthcare) and visualized with an imaging system (VersaDoc 3000, Bio-Rad), and the densitometric analysis of protein bands was performed using the Quantity One software (Bio-Rad).

Binding assay. The binding assays were performed as previously described (Matos et al., 2012a). Briefly, the total membranes (see total membranes preparation) were resuspended in a preincubation solution (containing $50 \mathrm{~mm}$ Tris, $1 \mathrm{~mm}$ EDTA, 2 mm EGTA, pH 7.4) and a sample was collected to determine the protein concentration using the BCA assay (Thermo Scientific). Adenosine deaminase (ADA; $2 \mathrm{U} / \mathrm{ml}$, Roche) was added and the membranes were incubated for $30 \mathrm{~min}$ at $37^{\circ} \mathrm{C}$ to remove endogenous adenosine. The mixtures were centrifuged at $25,000 \times g$ for $20 \mathrm{~min}$ at $4^{\circ} \mathrm{C}$, and the pelleted membranes were resuspended in Tris-Mg solution (containing $50 \mathrm{~mm}$ Tris and $10 \mathrm{mM} \mathrm{MgCl}_{2}$, for $\mathrm{A}_{2 \mathrm{~A}} \mathrm{R}$ binding, or $50 \mathrm{~mm}$ Tris and $2 \mathrm{~mm} \mathrm{MgCl}_{2}$, for $\mathrm{A}_{1} \mathrm{R}$ binding, $\mathrm{pH}$ 7.4) with $4 \mathrm{U} / \mathrm{ml} \mathrm{ADA}$. Binding with the selective $\mathrm{A}_{2 \mathrm{~A}} \mathrm{R}$ antagonist $\left[{ }^{3} \mathrm{H}\right]$ 4-(2-[7-amino-2-(2-furyl) [1,2,4]-triazolo[2,3-a][1,3,5]triazin-5-ylamino] ethyl)phenol (ZM241385; $3 \mathrm{~nm}$; PerkinElmer) was performed for $1 \mathrm{~h}$, and binding with the selective $A_{1} R$ antagonist $\left[{ }^{3} \mathrm{H}\right] 1$,3-dipropyl-8cyclopenthylxanthine (DPCPX; 2 nM; PerkinElmer) was performed for $2 \mathrm{~h}$, both at room temperature with $0.1-0.2 \mathrm{mg}$ of protein, with constant swirling. The binding reactions were stopped by the addition of $4 \mathrm{ml}$ of ice-cold Tris-Mg solution and filtration through Whatman GF/C glass microfiber filters (GE Healthcare) in a filtration system (Millipore). The radioactivity was measured after adding $5 \mathrm{ml}$ of scintillation liquid (PerkinElmer). The specific binding was expressed in femtomoles per milligram of protein and was estimated by subtraction of the nonspecific binding, which was measured in the presence of $12 \mu \mathrm{M}$ xanthine amine congener (Sigma), a mixed $\mathrm{A}_{1} \mathrm{R} / \mathrm{A}_{2 \mathrm{~A}} \mathrm{R}$ antagonist. All binding assays were performed in duplicate.

cAMP measurement. Striatal synaptosomes were prepared as previously described (Rebola et al., 2003). Briefly, the synaptosomal fraction was resuspended in KHR with ADA ( $4 \mathrm{U} / \mathrm{ml}$; Roche) and DPCPX ( $50 \mathrm{~nm}$; Tocris Bioscience) and was incubated for $10 \mathrm{~min}$ at $37^{\circ} \mathrm{C}$, to eliminate endogenous adenosine and eliminate putative $A_{1} R$-mediated effects. The mixture was then incubated with $(2 R, 3 R, 4 S, 5 R)-2$ (6-amino-2-(2-cyclohexylethylthio)-9H-purin-9-yl)-5-(hydroxymethyl) tetrahydrofuran-3,4-diol (PSB-12404; $50 \mathrm{~nm})$ or $(2 R, 3 S, 4 R, 5 R)-5-(6-$ amino-2-(2-cyclohexylethylthio)-9H-purin-9-yl)-3,4-dihydroxy-tetrahydro-furan-2-yl)methylphosphoric acid triethylammonium salt (PSB-12405; $50 \mathrm{nM}$ ) for $10 \mathrm{~min}$ at $37^{\circ} \mathrm{C}$, and the cAMP levels were measured as previously described (Chen et al., 2010). Briefly, the reaction was terminated by the addition of $5 \%$ ice-cold trichloroacetic acid (Ricca Chemical Company) and centrifuged for $10 \mathrm{~min}$ at $600 \times g$ to pellet the debris after homogenization. The trichloroacetic acid was extracted from the supernatant with water-saturated ether (Alfa Aesar). The aqueous extract was dried overnight and reconstituted in assay buffer. The samples were acetylated, and the levels of cAMP accumulated in synaptosomes were determined using a cAMP Complete ELISA kit (Assay Designs) according to the manufacturer's instructions.

Inorganic free phosphate measurement. The activity of ecto-5'nucleotidase was evaluated by measuring the formation of inorganic phosphate upon addition of AMP to striatal synaptosomes (Chan et al., 1986). Briefly, the synaptosomal fraction, prepared as previously described (Rebola et al., 2003), was resuspended in KHR and incubated for $5 \mathrm{~min}$ at $37^{\circ} \mathrm{C}$ to stabilize, followed by incubation with the tissuenonspecific alkaline phosphatase inhibitor (TNAP-I; $10 \mu \mathrm{M}$; Calbiochem) and/or AMP ( $1 \mathrm{~mm}$; Acros Organics) for $30 \mathrm{~min}$ at $37^{\circ} \mathrm{C}$. The mixture was then centrifuged at $14000 \times g$ at $4^{\circ} \mathrm{C}$ for $12 \mathrm{~min}$, and the inorganic free phosphate levels were measured from the supernatant using a Malachite Green Phosphate Assay kit (Cayman Chemical) according to the manufacturer's instructions.

Immunohistochemistry. Mice were anesthetized with avertin, and brain fixation was performed through transcardiac perfusion with $4 \%$ paraformaldehyde in PBS, postfixation overnight in PBS with 4\% paraformaldehyde, and cryopreservation in PBS containing 25\% sucrose. Frozen brains were sectioned ( $30 \mu \mathrm{m}$ coronal slices) with a Leica Microsystems CM3050S cryostat. The sections were first rinsed for 5 min with PBS at room temperature, and then permeabilized and blocked with PBS containing $0.2 \%$ Triton X-100 and 5\% donkey serum for $1 \mathrm{~h}$, incubated in the presence of the rabbit anti-murine CD73 antibody (1:500; Fausther et al., 2012) and/or mouse anti- $\mathrm{A}_{2 \mathrm{~A}} \mathrm{R}$ antibody (1:500; Millipore) overnight at room temperature, rinsed three times for $10 \mathrm{~min}$ in PBS, and then incubated with donkey anti-mouse and/or donkey anti-rabbit secondary antibodies conjugated with a fluorophore (1:200; Alexa Fluor 488 or Alexa Fluor 555, Invitrogen) for $2 \mathrm{~h}$ at room temperature. After rinsing three times for $10 \mathrm{~min}$ in PBS, the sections were mounted on slides and allowed to dry. Vectashield mounting medium with DAPI (Vector Laboratories) was applied as well as the cover glass. All sections were examined under a fluorescence Nikon Eclipse E600 microscope, with SPOT software 4.7 (Diagnostic Instruments).

Proximity ligation assay. The PLA was performed as previously described (Trifilieff et al., 2011) in brain sections prepared as described above. The sections were first rinsed in TBS $(0.1 \mathrm{~m}$ Tris, $\mathrm{pH} 7.4$, and $0.9 \% \mathrm{w} / \mathrm{v} \mathrm{NaCl}$ ) at room temperature, and then permeabilized and blocked with TBS with $1 \%$ BSA and $0.5 \%$ Triton X-100 for $2 \mathrm{~h}$ at room temperature. The slices were incubated with the primary antibodies, namely rabbit anti-murine CD73 (1:300; Fausther et al., 2012) and anti- $\mathrm{A}_{2 \mathrm{~A}} \mathrm{R}$ (1:300; Millipore) overnight at room temperature. After washing four times (30 min each) in TBS with $0.2 \%$ Triton X-100, the slices were incubated for $2 \mathrm{~h}$ at $37^{\circ} \mathrm{C}$ with the PLA secondary probes (1:5; Olink Bioscience) diluted under gentle agitation. After washing twice for 5 min with Duolink II Wash Buffer A (Olink Bioscience) with agitation at room temperature, the slices were incubated with the ligation-ligase solution (Olink Bioscience) for $30 \mathrm{~min}$ at $37^{\circ} \mathrm{C}$. After washing twice for $2 \mathrm{~min}$ with Duolink II Wash Buffer A with agitation at room temperature, the slices were incubated with polymerase (1: 40; Olink Bioscience) in the amplification solution (Olink Bioscience) for $100 \mathrm{~min}$ at $37^{\circ} \mathrm{C}$ under gentle agitation. After washing in decreasing concentrations $(2 \times, 1 \times, 0.2 \times, 0.02 \times$ for $10 \mathrm{~min}$ each $)$ of SSC buffers (Olink Bioscience), slices were mounted on slides and allowed to dry, and coverslips were placed with Duolink Mounting Medium (Olink Bioscience). Fluorescence images were acquired on an Axiovert 200M inverted confocal microscope (Carl Zeiss Microscopy) using a $40 \times$ objective, and the PLA puncta signals were quantified with the Image software, using a manual threshold to discriminate PLA puncta from background fluorescence. The built-in macro "Analyze Particles" was then used to count and characterize all objects in the thresholded image. Objects larger than $5 \mu \mathrm{m}^{2}$ were rejected, thereby effectively removing nuclei. The remaining objects were counted as PLA puncta.

Drug treatments and locomotor activity. The activity of the mice was assessed in standard polypropylene cages $(15 \times 25 \mathrm{~cm})$ and recorded with infrared photobeams (San Diego Instrument) in 5 min bins. Before drug treatments, the mice were habituated to the new room and new cage (except in the habituation experiment) for at least $2 \mathrm{~h}$. Two hours before the administration of 5-amino-7-(2-phenylethyl)-2-(2-furyl)-pyrazolo [4,3-e]-1,2,4-triazolo-[1,5-c]pyrimidine (SCH58261; $3 \mathrm{mg} / \mathrm{kg}$, i.p.; Tocris Bioscience), the animals were challenged with vehicle (intraperitoneally, $75 \%$ saline, $15 \%$ dimethylsulfoxide, $10 \%$ castor oil). In the amphetamine ( $2.5 \mathrm{mg} / \mathrm{kg}$, i.p.; Sigma) paradigm, the mice were injected in the same environment for 8 consecutive days and the locomotor activity was recorded. In the experiment with the $\mathrm{A}_{2 \mathrm{~A}} \mathrm{R}$ agonist drug or prodrug (see below), the mice were anesthetized with isoflurane and oxygen and were stereotaxically injected bilaterally in nucleus accumbens (anteroposterior $=+1 \mathrm{~mm}$ from bregma; mediolateral $= \pm 0.8 \mathrm{~mm}$ from midline; dorsoventral $=4.4 \mathrm{~mm}$ from the skull surface) with $1 \mu \mathrm{lof}$ $2 \mathrm{~mm}$ solution $(2 \mathrm{nmol}$ ) per side at a rate of $0.2 \mu \mathrm{l} / \mathrm{min}$. The activity was recorded after the mice recovered from the surgery.

The $\mathrm{A}_{2 \mathrm{~A}} \mathrm{R}$ agonist PSB-12404 and its phosphate prodrug PSB-12405 were synthesized as previously described (El-Tayeb et al., 2009).

Working memory. We first assessed working memory in a spontaneous alternation paradigm assessed in a Y-maze. Individual mice were placed at the end of one arm and allowed to freely explore the maze for $5 \mathrm{~min}$. The sequence of entrance in each arm was recorded, and the number of 
A

CD73 $\beta$-actin

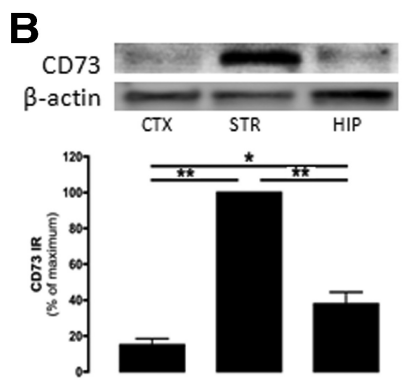

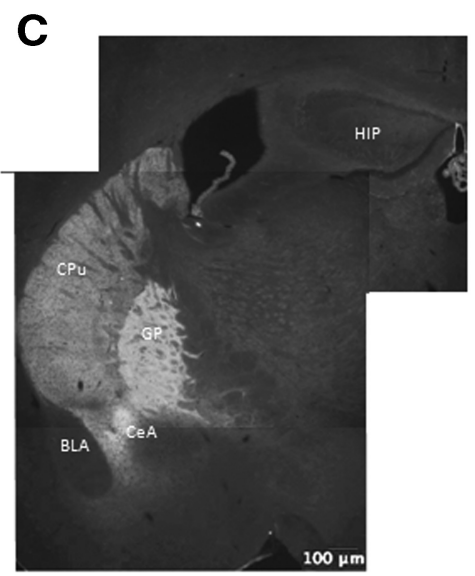

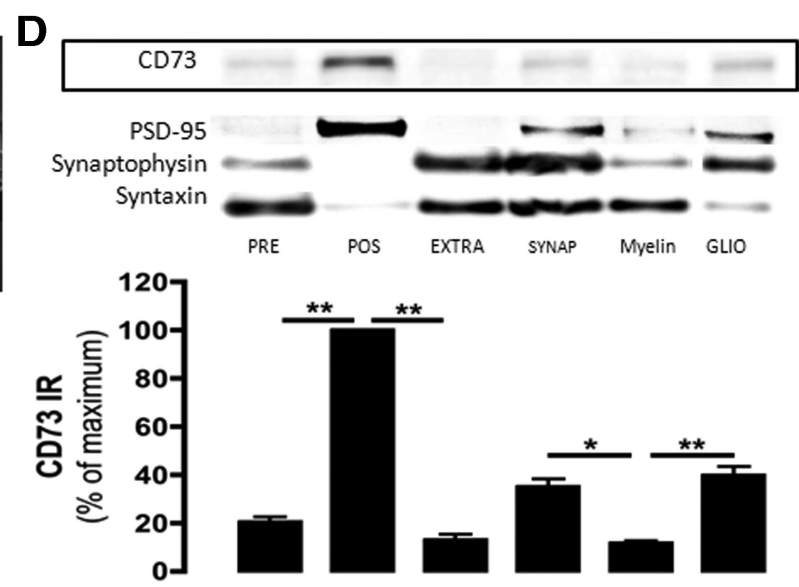

Figure 1. CD73 has a brain and subcellular distribution similar to that of $A_{2 A} R s$. $A, B$, Using an antibody selectively recognizing CD73 in the striatum of WT but not of CD73 KO mice, as shown in $\boldsymbol{A}$ (representative of $n=4)$, a Western blot analysis $(\boldsymbol{B})$ revealed that CD73 immunoreactivity was more densely located in the striatum (STR) than in the hippocampus (HIP) or cortex (CTX) ( $n=3$ ). C, Immunohistochemistry showed that CD73 displayed greater abundance in the globus pallidus (GP) and central nucleus of amygdala (CeA), than in the caudate-putamen (CPu), than in the hippocampus (HIP) and the basolateral amygdala (BLA) (image representative of $n=5$ ). $\boldsymbol{D}$, In the striatum, subcellular fractionation ( $n=2$ ) showed that CD73 had a higher density in postsynaptic density (POS), when compared with presynaptic (PRE) and extrasynaptic (EXTRA) fractions and was more densely located in synaptosomes (SYNAP) and gliosomes (GLIO) than in myelin preparations. Data are the mean \pm SEM, and a one-way ANOVA test was used followed by a Tukey's multiple-comparison test. ${ }^{*} p<0.01 ;{ }^{* *} p<0.001$.

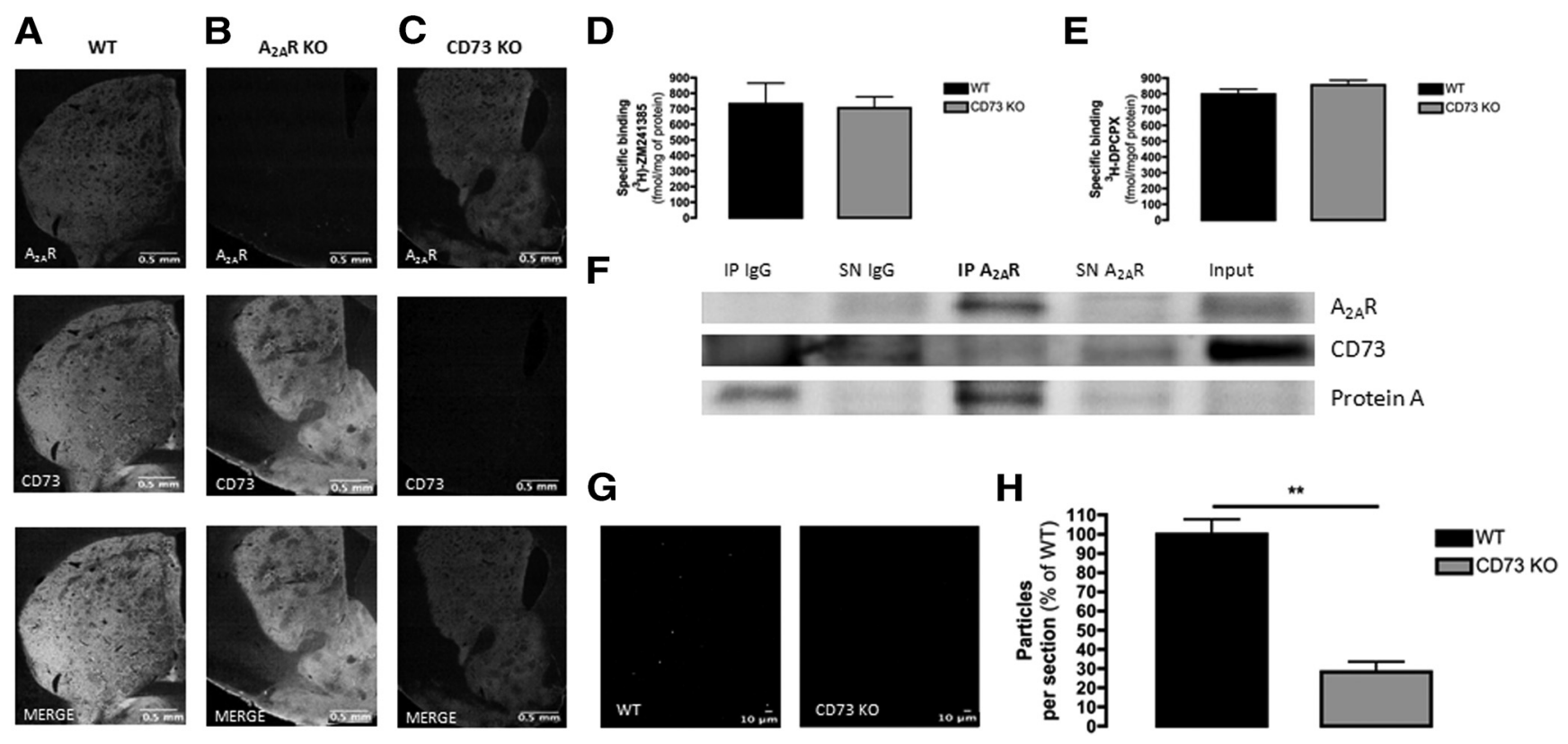

Figure 2. Colocalization and physical association of $C D 73$ and $A_{2 A} R s$ in the striatum. $A-C$, Macroscopic immunohistochemical colocalization of $C D 73$ and $A_{2 A} R s$ in striatal slices $(A ; n=5)$, with no immunoreactivity for $C D 73$ in $C D 73 \mathrm{KO}$ mice $(\boldsymbol{B} ; n=5)$, and no immunoreactivity for $A_{2 A} R s$ in $A_{2 A} R$ KO mice $(\boldsymbol{C} ; n=5)$. D, E, CD73 K0 mice had an identical density of binding sites for $A_{2 A} R s(D)$ and $A_{1} R s(E)$ when compared with their WT littermates $(n=5-6)$. $\boldsymbol{F}$, The pulldown of $A_{2 A} R s$ from striatal tissue revealed the co-immunoprecipitation of $C D 73$; indeed, the pulldown of $A_{2 A} R s$ (IP $A_{2 A} R$ ) revealed the presence of $A_{2 A} R s$ (top strip of blots), $C D 73$ (middle strip of blots), and protein A (bottom strip of blots), which were also present in the pulldown of $\operatorname{gG}(I P I g G) ;$ however, this condition (IP lgG) does not show immunoreactivity for $A_{2 A}$ Rs (top strip of blots) or CD73 (middle strip of blots). The input represents $5 \%$ of the sample before the pulldown, $S N A_{2 A} R$ and $S N$ IgG represent $20 \%$ of the supernatant of $A_{2 A} R$ and $\lg G$ pulldown, respectively (results representative of $n=3$ ). $\boldsymbol{G}, \boldsymbol{H}$, The intimate proximity between $\mathrm{A}_{2 \mathrm{~A}} \mathrm{Rs}$ and $C D 73$ was further shown by the signal recorded in a PLA in sections of the striatum from WT mice but not from CD73 KO mice. G shows representative PLA images of striatal sections from WT mice and CD73 K0 mice (representative from $n=3$ ) and $\boldsymbol{H}$ displays the quantification of the PLA experiments, with the WT having $100.0 \pm 7.758$ positive signals per slice and the CD73 KO having significantly less PLA signal (28.27 \pm 5.317 ). The data are the mean \pm SEM. ${ }^{* *} p<0.001$ using a Student's $t$ test.

alternations (sequential entrance in the three different arms) was quantified. The percentage of spontaneous alternation consists in the percentage of alternations of the total possible number of alternations (total number of arm changes -2 ).

We also assessed working memory in a more sensitive test using a radial arm maze (RAM) with eight arms as previously described (Singer et al., 2012). To motivate performance in the RAM memory tasks, the animals were maintained on a food deprivation regime, which was gradually introduced with a progressive reduction of the daily available food, until the animals reached a stable weight of not less than $85 \%$ of their ad libitum weight, at which time the food provided was stabilized. The RAM had eight identical and equally spaced arms ( $56 \mathrm{~cm}$ long, $12 \mathrm{~cm}$ wide) radiating from a central octagonal platform (side length $=12 \mathrm{~cm}$ ). The mice were exposed to the maze for $5 \mathrm{~min}$ each day with a food reward at the end of each arm. The habituation was performed until the animals finished the task within $5 \mathrm{~min}$. In the four baited arms paradigm, four of the eight arms were randomly set with a food reward and the mice were allowed to freely explore the maze until they ate the four food rewards. In 
the eight baited arms paradigm, the eight arms were set with a food reward and the animals were allowed to freely explore the maze until they ate the eight food rewards. Each time a mouse re-entered an arm where the reward had already been eaten, a working memory error (WME) was scored. Different groups of animals were used in the two RAM experiments. When testing the impact of the $\mathrm{A}_{2 \mathrm{~A}} \mathrm{R}$ and $\mathrm{A}_{1} \mathrm{R}$ antagonists SCH58261 and DPCPX (Tocris Bioscience), the drug or its vehicle solution was intraperitoneally administered to the animals $30 \mathrm{~min}$ before they were placed in the maze.

Statistical analysis. Results are presented as the mean \pm SEM. Data with one condition and one variable (e.g., genotype) were analyzed with Student's $t$ test. Data from more than one condition (e.g., different brain's preparations) were analyzed with repeated-measures ANOVA or one-way ANOVA followed by a Tukey's multiple-comparison post hoc test or by a Dunnett's multiple-comparison post hoc test (for comparison with specific controls). Data with more than one variable (e.g., genotype and time) and condition were analyzed with a two-way ANOVA followed by Bonferroni post hoc tests. Unless otherwise indicated, the significance level was $95 \%$.

\section{Results}

CD73, like $A_{2 A} R$, is most abundant in the striatum with a predominant postsynaptic localization

To determine the brain distribution of CD73, we first certified the selectivity of our anti-CD73 antibody, through Western blot analysis, which we found to recognize a band $(\approx 65 \mathrm{kDa})$ in striatal membranes of WT mice, without detectable signal in CD73 $\mathrm{KO}$ mice (Fig. $1 A$ ). We then compared the density of CD73 in different brain regions; Western blot analysis of total membranes showed that CD73 is more abundant in the striatum $(p<0.01)$ than in the hippocampus or prefrontal cortex (Fig. 1B). This was confirmed by immunohistochemical analysis (Fig. 1C), showing a higher CD73 immunoreactivity in different basal ganglia areas, as well as in the central nucleus of amygdala, when compared with the hippocampus or cerebral cortex. Within the basal ganglia, CD73 immunoreactivity was higher in the globus pallidus than in the caudate putamen and nucleus accumbens.

We next attempted to define the cellular and subsynaptic localization of CD73 in the basal ganglia. In accordance with the previously described localization of CD73 in astrocytes and neurons (Kreutzberg et al., 1978; Schoen and Kreutzberg, 1997), we found that CD73 was more abundant in gliosomes (astrocytic plasmalemmal vesicles) and synaptosomes than in myelin membranes (Fig. 1D). Furthermore, within synapses CD73 was more abundantly located in the postsynaptic density than in the presynaptic active zone and was scarcely located in perisynaptic regions (extrasynaptic fraction) (Fig. 1D). Altogether, this striatum-enriched pattern of CD73 together with its predomi-

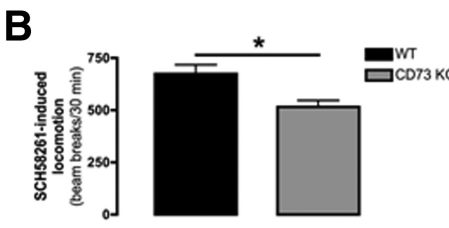

C
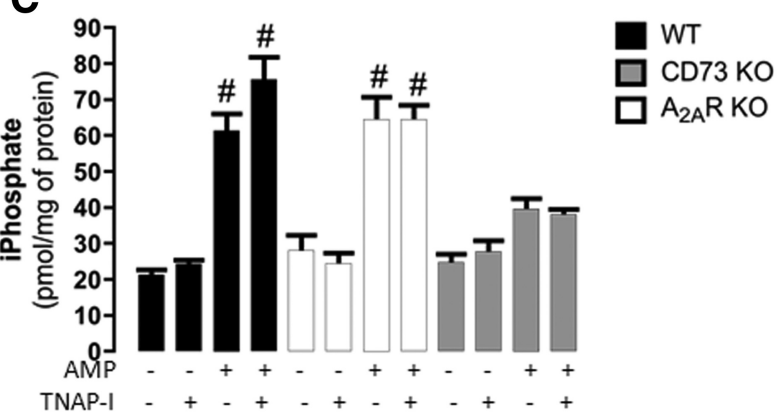
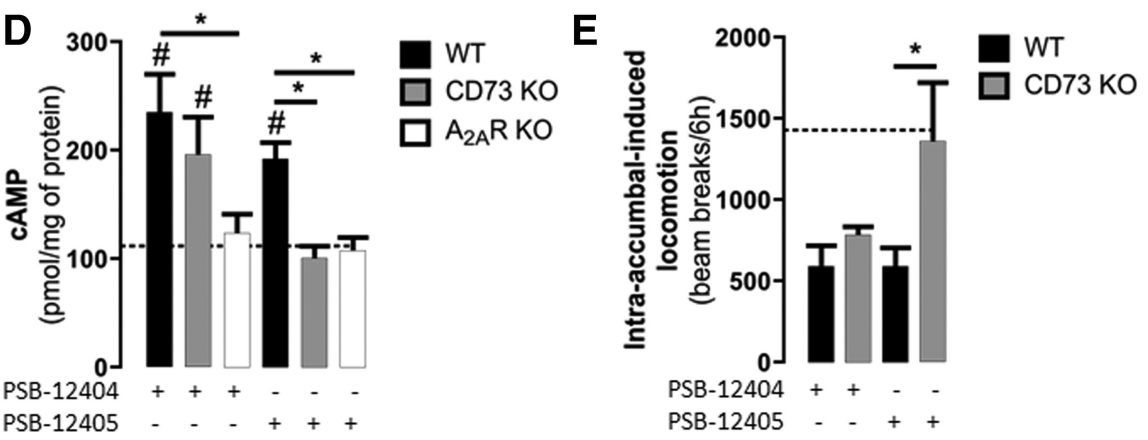

Figure 3. CD73 activity provides the adenosine activating striatal $A_{2 A} R s$. $A, B$, Acute administration of the $A_{2 A} R$ antagonist $S C H 58261$ (3 mg/kg, i.p.) induced hyperlocomotion. $\boldsymbol{A}$ represents the mean \pm SEM of beam breaks per 5 min, whereas $\boldsymbol{B}$ represents the mean \pm SEM of the total number of beam breaks in 30 min after SCH58261 administration in WT and CD73 KO mice ( $n=$ striatal synaptosomes from CD73 KO mice cannot $(n=4-7)$; furthermore, TNAP-I (10 $\mu \mathrm{m})$ failed to affect the extracellular ( re horizontal dash line) in striatal synaptosomes from WT mice, whereas only the drug but not the prodrug breaks $/ 6 \mathrm{~h}, n=17)$. The data are the mean \pm SEM. ${ }^{*} p<0.05$ between genotypes (as indicated by the top bars) using a Student's $t$ test in $\boldsymbol{B}$ and $\boldsymbol{E}$ or using a one-way ANOVA test followed by a Dunnett's multiple-comparison test to WT mice as control in $\boldsymbol{D}$ \#differences from control (i.e., no added drugs) with $p<0.001$ using a one-way ANOVA test followed by a Tukey's multiplecomparison test in $\boldsymbol{C}$; and $p<0.05$ using a one-way ANOVA test followed by a Dunnett's multiple-comparison test to control in $\boldsymbol{D}$.

nant postsynaptic localization suggests that CD73 is concentrated in the dendrites of striatal medium spiny neurons, precisely where $\mathrm{A}_{2 \mathrm{~A}}$ Rs are more densely present, a conclusion that awaits to be confirmed by electronic microscopy studies.

Colocalization and physical association of CD73 and $A_{2 A} R s$ in the striatum

The observed similar greater abundance of CD73 and $\mathrm{A}_{2 \mathrm{~A}} \mathrm{Rs}$ in the striatum together with the proposed functional association between ATP-derived adenosine and the activation of $\mathrm{A}_{2 \mathrm{~A}} \mathrm{R}$ (Cunha et al., 1996; Rebola et al., 2008), led us to investigate the association between CD73 and $\mathrm{A}_{2 \mathrm{~A}} \mathrm{R}$. Double immunohistochemistry analysis showed that CD73 colocalized with $\mathrm{A}_{2 \mathrm{~A}} \mathrm{R}$ in the striatum (Fig. $2 A$ ). We confirmed the selectivity of each antibody labeling by showing the absence of the putative $\mathrm{A}_{2 \mathrm{~A}} \mathrm{R}$ signal in $A_{2 \mathrm{~A}} \mathrm{R} \mathrm{KO}$ mice (Fig. 2B) and the absence of the putative CD73 
signal in CD73 KO mice (Fig. 2C); furthermore, there do not seem be overt changes of CD73 immunoreactivity in $\mathrm{A}_{2 \mathrm{~A}} \mathrm{R}$ KO mice (Fig. $2 B$ ) or of $A_{2 A} R$ signal in CD73 KO mice (Fig. 2C). In agreement, no changes were found in the binding density of either the selective $\mathrm{A}_{2 \mathrm{~A}} \mathrm{R}$ antagonist ( $\left[{ }^{3} \mathrm{H}\right] \mathrm{ZM}$ 241385; Fig. $2 D$ ) or of the selective $A_{1} R$ antagonist $\left(\left[{ }^{3} \mathrm{H}\right] D P C P X ;\right.$ Fig. $\left.2 E\right)$ to total striatal membranes of CD73 KO mice compared with WT mice.

The physical interaction between $\mathrm{A}_{2 \mathrm{~A}}$ Rs and CD73 was further prompted by the observation that the pulldown of striatal $\mathrm{A}_{2 \mathrm{~A}} \mathrm{R}$ revealed a co-immunoprecipitation with $\mathrm{CD} 73$ (Fig. $2 F$ ). To consolidate this suggested association between $\mathrm{CD} 73$ and $\mathrm{A}_{2 \mathrm{~A}} \mathrm{Rs}$ in the striatum, we used a PLA approach that showed a selective physical proximity ( $\leq 16 \mathrm{~nm}$ ) between $\mathrm{A}_{2 \mathrm{~A}} \mathrm{R}$ and CD73 in WT but not CD73 KO mice (Fig. 2G,H).

\section{CD73-derived adenosine is required for striatal $A_{2 A} R$ activation and function}

Since it is well documented that $\mathrm{A}_{2 \mathrm{~A}} \mathrm{R}$ antagonists trigger a hyperlocomotion through the blockade of striatopallidal $\mathrm{A}_{2 \mathrm{~A}}$ Rs (Shen et al., 2008), we tested whether CD73 would be responsible for the formation of the adenosine tonically activating this population of $\mathrm{A}_{2 \mathrm{~A}} \mathrm{Rs}$. In accordance with this hypothesis, we report that the hyperlocomotion triggered by the selective $\mathrm{A}_{2 \mathrm{~A}} \mathrm{R}$ antagonist SCH58261 (3 mg/kg, i.p.) had significantly $(p<0.01)$ lower amplitude in $\mathrm{CD} 73 \mathrm{KO}$ mice when compared with their WT littermates (Fig. $3 A, B$ ). This is probably due to the lack of AMPderived adenosine to tonically activate striatal $A_{2 A}$ Rs since we now report that striatal synaptosomes from WT and $\mathrm{A}_{2 \mathrm{~A}} \mathrm{R} K \mathrm{KO}$ mice were able to dephosphorylate AMP, as gauged from the formation of inorganic phosphate, whereas this did not occur in striatal synaptosomes from CD73 KO mice (Fig. 3C). This conclusion reached in other brain preparations that CD73 is the predominant activity responsible for the formation of adenosine from extracellular AMP, as further confirmed by the lack of impact of the alkaline phosphatase inhibitor TNAP-I $(10 \mu \mathrm{M})$ on the extracellular catabolism of AMP in striatal synaptosomes from either WT or CD73 KO mice (Fig. $3 C$ ) extends to striatal preparations.

To reinforce the direct relation between $\mathrm{CD} 73$ and $\mathrm{A}_{2 \mathrm{~A}} \mathrm{R}$ in the striatum, we took advantage of a novel $\mathrm{A}_{2 \mathrm{~A}} \mathrm{R}$ pro-agonist (PSB12405), which needs to be dephosphorylated by CD73 to generate the active form of the $\mathrm{A}_{2 \mathrm{~A}} \mathrm{R}$ agonist PSB-12404 (El-Tayeb et al., 2009; Flögel et al., 2012). We first confirmed in striatal synaptosomes that the pro-agonist indeed activated $\mathrm{A}_{2 \mathrm{~A}} \mathrm{Rs}$ in a CD73dependent manner, by comparing the ability of the drug and prodrug to enhance cAMP levels, an established measure of $A_{2 A} R$ activity in the striatum (Svenningsson et al., 1998; Corvol et al., 2001). We found that the prodrug increased cAMP levels in striatal synaptosomes from WT mice, but not in those from either CD73 KO or $\mathrm{A}_{2 \mathrm{~A}} \mathrm{R}$ KO mice (Fig. $3 D$ ); whereas, the $\mathrm{A}_{2 \mathrm{~A}} \mathrm{R}$ agonist (PSB-12404) increased cAMP levels in WT and CD73 KO mice, but not in $\mathrm{A}_{2 \mathrm{~A}} \mathrm{R}$ KO mice (Fig. 3D). This shows that PSB-12405 requires $\mathrm{CD} 73$ activity to activate striatal $\mathrm{A}_{2 \mathrm{~A}} \mathrm{Rs}$, which allows using this pro-agonist to test whether $\mathrm{CD} 73$ is responsible for generating the adenosine that specifically controls the impact of $\mathrm{A}_{2 \mathrm{~A}}$ Rs on striatal-related behavioral responses.

In agreement with the previously reported hypolocomotor effect of $\mathrm{A}_{2 \mathrm{~A}} \mathrm{R}$ agonists directly injected in the nucleus accumbens (Hauber and Münkle, 1997; Nagel et al., 2003), the bilateral intraaccumbal injection of PSB-12405 reduced locomotion in the WT mice to an extent greater than that in the CD73 KO mice (Fig. $3 E)$. Instead, when PSB-12404 was injected no differences were found between the two genotypes (Fig. 3E).
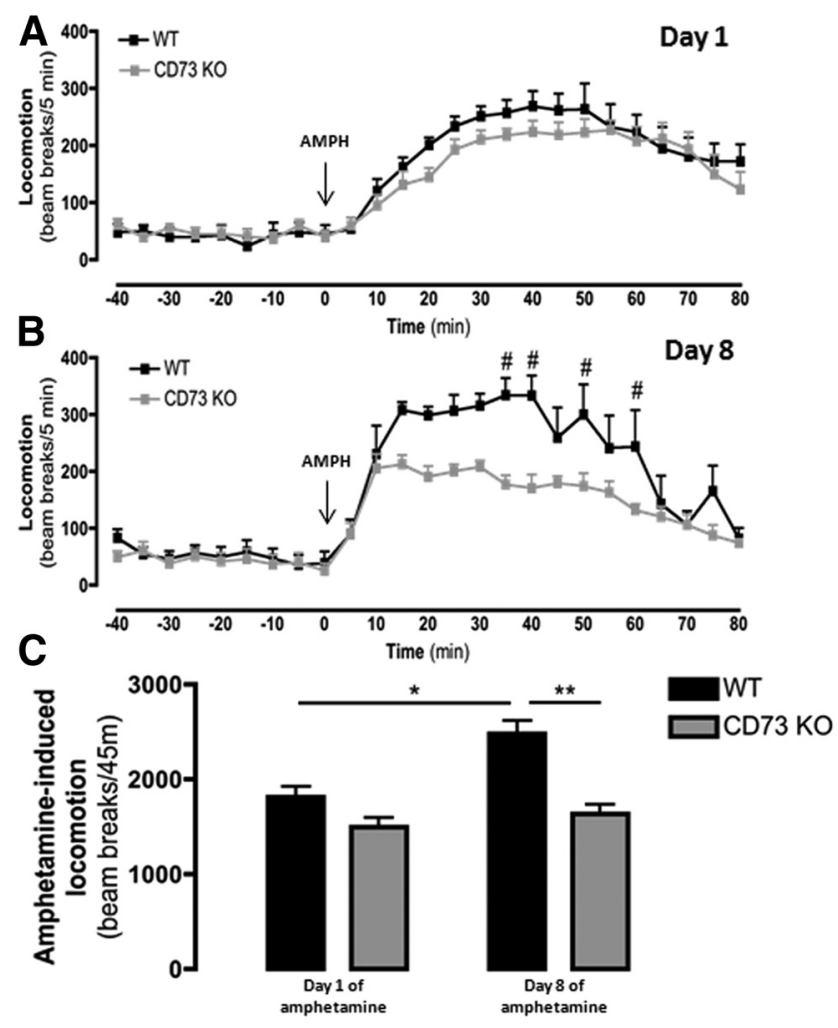

Figure 4. CD73 KO mice show no locomotor sensitization to amphetamine. CD73 KO $(n=7)$ and WT $(n=6)$ mice showed identical hyperlocomotion induced by an acute single administration of amphetamine $(\boldsymbol{A})$. However, CD73 K0 mice showed no sensitization to amphetamine after being challenged for 8 consecutive days, in contrast to the WT mice that showed a significant increase in locomotion $(B, C)$. Data are the mean $\pm S E M$. ${ }^{\#} p<0.05$, using a two-way ANOVA followed by Bonferroni post hoc tests in $\boldsymbol{B} ;{ }^{*} p<0.01$, using repeated-measures ANOVA; ${ }^{* *} p<0.001$, using a two-way ANOVA followed by Bonferroni post hoc test in $\boldsymbol{C}$.

\section{CD73 KO mice show no sensitization to amphetamine,} mimicking $\mathrm{A}_{2 \mathrm{~A}} \mathrm{R}$ KO phenotype

It was previously shown that global- $\mathrm{A}_{2 \mathrm{~A}} \mathrm{R} \mathrm{KO}$ mice (Chen et al., 2003), as well as forebrain- $A_{2 A} R$ KO mice (Bastia et al., 2005), do not develop psychomotor sensitization to amphetamine, which provides an additional opportunity to probe the functional association between $\mathrm{CD} 73$ and the activation of $\mathrm{A}_{2 \mathrm{~A}} \mathrm{Rs}$.

CD73 depletion had no effect on the locomotor response to habituation to a novel environment or to the habituation to a saline injection (data not shown). Furthermore, there was no difference between CD73 KO and WT mice in the locomotor response to the first administration of a low dose $(2.5 \mathrm{mg} / \mathrm{kg})$ of amphetamine (Fig. $4 A, C$ ). However, continued daily treatment with this low dose of amphetamine markedly enhanced (sensitized) locomotor responses in control WT mice $(p<0.05$, day 8 vs day 1 ), whereas no sensitization to amphetamine was observed in CD73 KO mice (Fig. 4B, C).

\section{CD73 KO mice display improved working memory,} mimicking the phenotype by genetic and pharmacological inactivation of $A_{2 \mathrm{~A}} \mathrm{Rs}$

It was previously shown that $\mathrm{A}_{2 \mathrm{~A}} \mathrm{Rs}$ control working memory performance: indeed, it is deficient in $\mathrm{A}_{2 \mathrm{~A}} \mathrm{R}$-overexpressing mice (Giménez-Llort et al., 2007) and improved in global- $\mathrm{A}_{2 \mathrm{~A}} \mathrm{R} \mathrm{KO}$ mice as well as forebrain- $\mathrm{A}_{2 \mathrm{~A}} \mathrm{R} K \mathrm{KO}$ and striatal- $\mathrm{A}_{2 \mathrm{~A}} \mathrm{R}$ KO mice (Zhou et al., 2009; Wei et al., 2011). We now report that CD73 $\mathrm{KO}$ mice displayed an improved working memory compared 
with WT mice, when tested in the spontaneous alternation paradigm in a Y-maze (Fig. 5A), without changes in their locomotion (Fig. $5 B$ ). In addition, CD73 KO mice made fewer working memory errors than WT mice in the eight baited arms version of the eight radial arm maze (Fig. $5 C, D)$. This result was further validated in the four baited arms version of the eight radial arm maze with a separate group of mice (data not shown). Thus, despite the limitations of each test in the evaluation of working memory, taken together, these results show a consistent improvement of working memory performance when CD73 is depleted. To discount developmental changes in the $\mathrm{KO}$ lines, we tested the effect of an acute blockade of $\mathrm{A}_{2 \mathrm{~A}} \mathrm{Rs}$ in two different paradigms of working memory, using a selective $\mathrm{A}_{2 \mathrm{~A}} \mathrm{R}$ antagonist (SCH58261, $0.03 \mathrm{mg} / \mathrm{kg}$, i.p.; the same dose that was able to blunt amphetamine sensitization without changing basal locomotion; Bastia et al., 2005). To discard the involvement of the other main adenosine receptor in the phenotype, we also tested the effect of an acute blockade of $A_{1}$ Rs using a selective $A_{1} R$ antagonist (DPCPX, $0.03 \mathrm{mg} / \mathrm{kg}$, i.p.) in the same paradigms. The mice that received SCH58261 $30 \mathrm{~min}$ before testing displayed an improved working memory compared with the mice that received either vehicle (control) or DPCPX, when tested in the spontaneous alternation paradigm in the Y-maze test (Fig. $5 E$ ), without changes in their locomotion (Fig. $5 F$ ). A similar result was obtained with a higher dose of DPCPX (0.3 $\mathrm{mg} / \mathrm{kg}$, i.p.; data not shown). In addition, mice treated with SCH58261 made fewer working memory errors than either control or DPCPX-treated mice in the eight baited arms (Fig. 5G,H) version of the eight radial arm maze. This phenotype resulting from the pharmacological blockade of $\mathrm{A}_{2 \mathrm{~A}} \mathrm{Rs}$ and not $A_{1} R s$ is superimposable to that of $A_{2 A} R$ KO mice and also parallels that of CD73 $\mathrm{KO}$ mice, further strengthening our contention that CD73 is responsible for the formation of the adenosine that tonically activates striatal $\mathrm{A}_{2 \mathrm{~A}} \mathrm{Rs}$.

\section{Discussion}

We here showed that the activity of CD73, the major enzyme dephosphorylating AMP to adenosine in the CNS, and therefore responsible for the last enzymatic step in the formation of extracellular ATP-derived adenosine, has a crucial role in the activation of striatal $\mathrm{A}_{2 \mathrm{~A}}$ Rs. The intrinsic relation between CD73 and $\mathrm{A}_{2 \mathrm{~A}} \mathrm{Rs}$ is supported by their anatomical localization and physical proximity in the striatum. The colocalization of CD73 and $\mathrm{A}_{2 \mathrm{~A}} \mathrm{Rs}$ in the striatum is demonstrated by their similar distribution patterns in the basal ganglia as well as by the postsynaptic enrichment of these two molecules and their physical proximity, documented by co-immunoprecipitation and proximity ligation assays. After showing that the deletion of CD73 abolished the extracellular dephosphorylation of AMP, the functional associa-
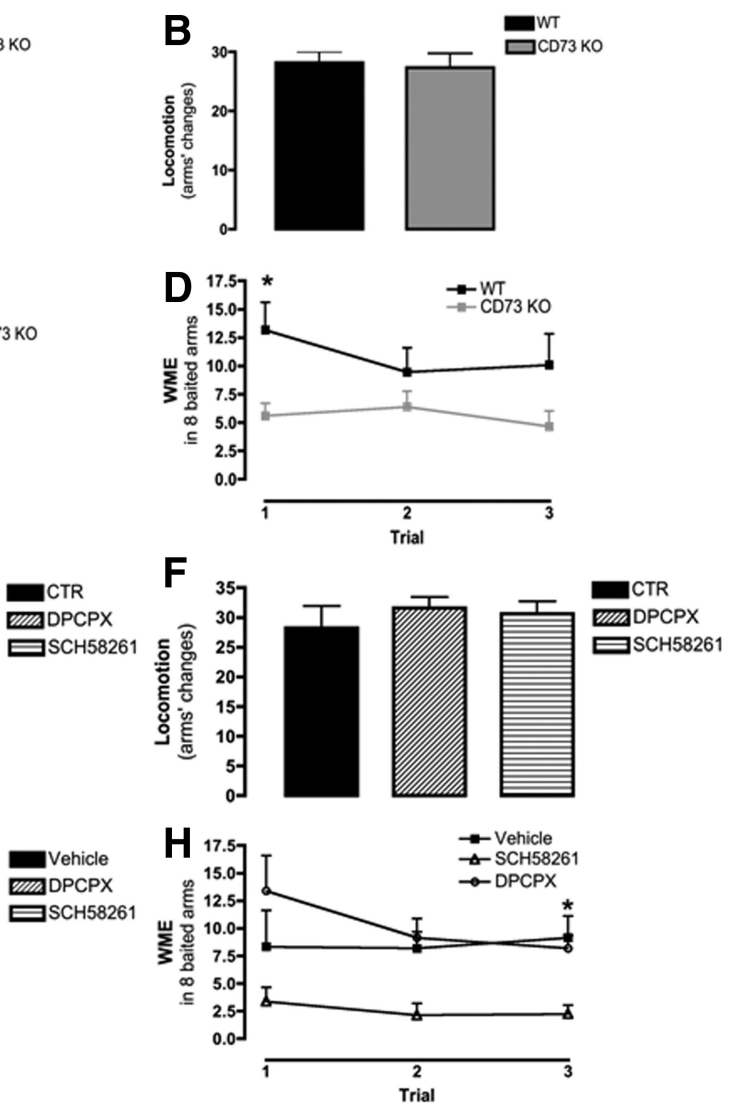

Figure 5. CD73 K0 mice display an improved working memory, which is mimicked by the acute blockade of $A_{2 A} R s$, but not $A_{1} R s$. CD73 K0 mice have an improved working memory when tested in a Y-maze paradigm (A) analyzing their spontaneous alternation

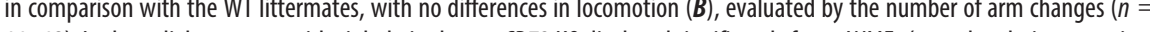
spontaneous alternation in comparison with the control group (vehicle, intraperitoneally), with no differences in the mice 政 $A_{1} R$ antagonist (DPCPX, $0.03 \mathrm{mg} / \mathrm{kg}$, i.p.) (E), and no differences in locomotion $(\boldsymbol{F})$, evaluated by the fewer WMEs in comparison with the control group, with no differences in the mice treated with a selective $A_{1}$ R antagonist $(n=8)$. Data are the mean \pm SEM. ${ }^{*} p<0.05$ and ${ }^{* *} p<0.01$ using a Student's $t$ test $(\boldsymbol{A}-\boldsymbol{C})$, a one-way ANOVA test followed by a Dunnett's multiple-comparison test to control $(\boldsymbol{E}-\boldsymbol{G})$, or a two-way ANOVA followed by Bonferroni post hoc test $(\boldsymbol{D}, \boldsymbol{H})$.

tion between CD73 activity and the activation of striatal $\mathrm{A}_{2 \mathrm{~A}} \mathrm{Rs}$ was validated by the abolishment of ex vivo (i.e., cAMP formation) as well as in vivo effects (hypolocomotor) of a novel prodrug for $\mathrm{A}_{2 \mathrm{~A}} \mathrm{R}$ agonism (El-Tayeb et al., 2009; Flögel et al., 2012) in either $\mathrm{CD} 73 \mathrm{KO}$ or $\mathrm{A}_{2 \mathrm{~A}} \mathrm{R} \mathrm{KO}$ mice.

The functional association between CD73 activity and the activation of striatal $\mathrm{A}_{2 \mathrm{~A}}$ Rs was further confirmed in vivo, in three major behavioral responses that have previously been shown to involve $\mathrm{A}_{2 \mathrm{~A}} \mathrm{R}$ activation (i.e., hypolocomotion, decreased working memory and behavioral sensitization to psychoactive drugs). Thus, we here showed that CD73 KO mice display a reduced hyperlocomotor response to a supramaximal dose of a selective $\mathrm{A}_{2 \mathrm{~A}} \mathrm{R}$ antagonist (SCH58261), which indicates that CD73 KO mice have less adenosine that is selectively activating striatal $\mathrm{A}_{2 \mathrm{~A}}$ Rs responsible for the hyperlocomotor effect (Yu et al., 2008). We are not suggesting that CD73 KO mice have in general lower levels of adenosine since they display a normal $A_{1} R$-mediated control of synaptic transmission (Zhang et al., 2012); instead, these data indicate that CD73 KO mice have lower levels of adenosine near $\mathrm{CD} 73-\mathrm{A}_{2 \mathrm{~A}} \mathrm{R}$ complexes. In addition, we have previously shown that the inactivation of $\mathrm{A}_{2 \mathrm{~A}} \mathrm{Rs}$ (Chen et al., 2003), 
namely of forebrain $A_{2 A} R s$, as well as acute $A_{2 A} R$ blockade by SCH58261 (0.03 mg/kg) (Bastia et al., 2005), abolishes the psychomotor sensitization to amphetamine, without changing the basal locomotion; notably, we now report a similar phenotype in CD73 KO mice. It was also shown that inactivation of $A_{2 A} R s$ (Zhou et al., 2009), namely striatal $A_{2 \mathrm{~A}}$ Rs (Wei et al., 2011), enhances working memory performance, a similar phenotype as now observed after $\mathrm{A}_{2 \mathrm{~A}} \mathrm{R}$ antagonist administration, as well as in CD73 KO mice, but not after $A_{1} R$ antagonist administration. All together, the parallel modifications of these behavioral responses by eliminating $\mathrm{CD} 73$ or $\mathrm{A}_{2 \mathrm{~A}} \mathrm{Rs}$ but not $\mathrm{A}_{1} \mathrm{Rs}$ (Giménez-Llort et al., 2002, 2005), as well as upon acute $A_{2 A} R s$, but not $A_{1} R$ blockade, prompt the conclusion that $\mathrm{CD} 73$ is responsible for the formation of the adenosine that activates $\mathrm{A}_{2 \mathrm{~A}} \mathrm{Rs}$ in the striatum.

This proposed activation of $\mathrm{A}_{2 \mathrm{~A}} \mathrm{Rs}$ selectively by CD73mediated formation of adenosine seems to be a general feature of $\mathrm{A}_{2 \mathrm{~A}} \mathrm{Rs}$ not only in the striatum, but also in other tissues and cell types. Indeed, it was shown that the inhibition of CD73 selectively blunts the ability of $A_{2 A}$ Rs to control synaptic plasticity in hippocampal synapses (Rebola et al., 2008) or synaptic adaptation at the neuromuscular junction (Correia-de-Sá et al., 1996; Cunha et al., 1996a), as well as the control of glutamate-induced toxicity in cultured granular cells (Boeck et al., 2007). Furthermore, the control by $\mathrm{A}_{2 \mathrm{~A}}$ Rs of the vascular tone (Koszalka et al., 2004; Zernecke et al., 2006) and of the immune-inflammatory system has also been shown to strictly depend on the activity of CD73 (Deaglio et al., 2007; Peng et al., 2008; Flögel et al., 2012). The tight association between $\mathrm{CD} 73$ and $\mathrm{A}_{2 \mathrm{~A}} \mathrm{Rs}$ is further heralded by the observation that several conditions trigger a coordinated induction or repression of CD73 and $\mathrm{A}_{2 \mathrm{~A}} \mathrm{R}$ expression (Napieralski et al., 2003; Deaglio et al., 2007), strongly supporting the view that these two molecules are tightly interconnected.

Notably, there seems to be a selective association of CD73mediated formation of adenosine with the activation of facilitatory $\mathrm{A}_{2 \mathrm{~A}} \mathrm{Rs}$ rather than with the more abundant inhibitory $\mathrm{A}_{1} \mathrm{Rs}$ in the nervous system (for review, see Fredholm et al., 2005). Indeed, several groups concluded that the inhibition or genetic deletion of CD73 failed to affect the modulation of synaptic transmission by $\mathrm{A}_{1}$ Rs either in physiological or pathological conditions (Lloyd et al., 1993; Brundege and Dunwiddie, 1996; Cunha et al., 1996; Lovatt et al., 2012; Zhang et al., 2012), in contrast to the conclusions derived from a transgenic mouse with hampered release of gliotransmitters (Pascual et al., 2005). This dissociation between CD73 activity and $\mathrm{A}_{1} \mathrm{R}$ activation is further supported by the different localization of CD73 and $\mathrm{A}_{1} \mathrm{Rs}$ throughout the brain (Lee et al., 1986; Fastbom et al., 1987). This is in general agreement with the idea that the activation of $A_{1} R s$ results from the activity-dependent metabolic control of adenosine kinase (Diógenes et al., 2012) producing a direct outflow of adenosine as such (Lloyd et al., 1993; Brundege and Dunwiddie, 1998; Frenguelli et al., 2003). However, it cannot be excluded that ATP-derived adenosine might also activate $A_{1} R s$ in particular systems, such as in the control of tubuloglomerular feedback (Thomson et al., 2000) or of nociception, which requires the participation of alkaline phosphatase (Zylka et al., 2008; Sowa et al., 2010), which we now ruled out to contribute for the extracellular catabolism of AMP in striatal synapses.

This selective activation of $\mathrm{A}_{2 \mathrm{~A}}$ Rs by CD73-mediated adenosine formation provides direct support to the previous proposal to understand the differential activation of inhibitory $A_{1}$ Rs and facilitatory $\mathrm{A}_{2 \mathrm{~A}} \mathrm{Rs}$ according to the functional needs of neuronal circuits (Cunha, 2008). Thus, it is proposed that the activation of synaptic $A_{2 \mathrm{~A}}$ Rs (Rebola et al., 2005) is designed for local adaptive functional changes that are driven by activity-dependent experience (Cunha, 2008); therefore, the source of the adenosine designed to activate $\mathrm{A}_{2 \mathrm{~A}}$ Rs should be locally produced, solely within the recruited synapses. The presently observed localization of CD73 within synapses (see also Cunha et al., 2000), mainly at the postsynaptic density, contributes to this main aim of converting the activity-dependent ATP release from synapses (Wieraszko et al., 1989; Cunha et al., 1996b; Pankratov et al., 2006) into the adenosine responsible for the local activation of $\mathrm{A}_{2 \mathrm{~A}} \mathrm{R}$. In addition to astrocytic release of ATP (Halassa et al., 2009; Schmitt et al., 2012), the localization of the newly identified vesicular nucleotide transport within synapses, namely at the nerve terminal (Larsson et al., 2012), heralds our proposal of a local synaptic release of ATP as the possible source of neuronal CD73-mediated adenosine signaling acting through $\mathrm{A}_{2 \mathrm{~A}} \mathrm{Rs}$. The present study focused only on the relation between adenosine formation and $\mathrm{A}_{2 \mathrm{~A}} \mathrm{R}$ activation; it remains to be explored whether the clearance of adenosine by the large family of nucleoside transporters (Parkinson et al., 2011), which activity is controlled by $\mathrm{A}_{2 \mathrm{~A}} \mathrm{Rs}$ in synapses (Duarte-Pinto et al., 2005), might also play a role in restraining CD73-generated adenosine for the activation of $\mathrm{A}_{2 \mathrm{~A}} \mathrm{Rs}$, as was recently proposed (Nam et al., 2013).

It also remains to be defined whether the association between CD73-mediated formation of ATP-derived adenosine and the activation of $A_{2 A}$ Rs observed under near-physiological conditions can also be extrapolated to pathological brain conditions. Indeed, $\mathrm{A}_{2 \mathrm{~A}} \mathrm{R}$ blockade is established to afford a robust neuroprotection in animal models of brain diseases ranging from Alzheimer's or Parkinson's diseases to epilepsy or ischemia (Chen et al., 1999, 2001; El Yacoubi et al., 2008; Canas et al., 2009). However, despite the extensive characterization of the role of $A_{2 A} R s$, its source of adenosine has been unclear. Remarkably, noxious brain conditions trigger an enhancement of the extracellular levels of ATP (Di Virgilio, 2000). Since we confirmed that the extracellular conversion of AMP into adenosine seems to be wiped out in CD73 KO mice (Klyuch et al., 2012; Lovatt et al., 2012; Zhang et al., 2012), with no compensation of alternative enzymatic activities such as alkaline phosphatase (Langer et al., 2008), it is tempting to consider the possibility that the manipulation of CD73 might afford a benefit similar to that observed for $\mathrm{A}_{2 \mathrm{~A}} \mathrm{R}$ blockade (for review, see Cunha, 2005; Chen et al., 2007). This might eventually provide a functional role for the localization of CD73 in astrocytic membranes (Kreutzberg et al., 1978), now also confirmed to be present in gliosomes, which joins the proposed role of glial $\mathrm{A}_{2 \mathrm{~A}}$ Rs in neurodegeneration (Yu et al., 2008; Matos et al., 2012b).

In summary, the present study provides the first molecular and behavioral demonstration that $\mathrm{CD} 73$ activity is responsible for the formation of the adenosine that activates striatal $A_{2 A} R s$. Therefore, our work points to CD73 as a new target that can fine tune $\mathrm{A}_{2 \mathrm{~A}} \mathrm{R}$ activity, paving the way to consider CD73 as a potential alternative target to $\mathrm{A}_{2 \mathrm{~A}} \mathrm{Rs}$ to manipulate activity-dependent synaptic adaptation and eventually neurodegeneration.

\section{References}

Bastia E, Xu YH, Scibelli AC, Day YJ, Linden J, Chen JF, Schwarzschild MA (2005) A crucial role for forebrain adenosine $A_{2 A}$ receptors in amphetamine sensitization. Neuropsychopharmacology 30:891-900. CrossRef Medline

Boeck CR, Kroth EH, Bronzatto MJ, Vendite D (2007) Effect of the L- or D-aspartate on ecto-5'nucleotidase activity and on cellular viability in cultured neurons: participation of the adenosine $\mathrm{A}_{2 \mathrm{~A}}$ receptors. Amino Acids 33:439-444. CrossRef Medline 
Boison D (2006) Adenosine kinase, epilepsy and stroke: mechanisms and therapies. Trends Pharmacol Sci 27:652-658. CrossRef Medline

Boison D (2011) Modulators of nucleoside metabolism in the therapy of brain diseases. Curr Top Med Chem 11:1068-1086. CrossRef Medline

Brundege JM, Dunwiddie TV (1996) Modulation of excitatory synaptic transmission by adenosine released from single hippocampal pyramidal neurons. J Neurosci 16:5603-5612. Medline

Brundege JM, Dunwiddie TV (1998) Metabolic regulation of endogenous adenosine release from single neurons. Neuroreport 9:3007-3011. CrossRef Medline

Canas PM, Porciúncula LO, Cunha GM, Silva CG, Machado NJ, Oliveira JM, Oliveira CR, Cunha RA (2009) Adenosine $A_{2 A}$ receptor blockade prevents synaptotoxicity and memory dysfunction caused by $\beta$-amyloid peptides via p38 mitogen-activated protein kinase pathway. J Neurosci 29: 14741-14751. CrossRef Medline

Chan KM, Delfert D, Junger KD (1986) A direct colorimetric assay for $\mathrm{Ca}^{2+}$-stimulated ATPase activity. Anal Biochem 157:375-380. CrossRef Medline

Chen CC, Yang CH, Huang CC, Hsu KS (2010) Acute stress impairs hippocampal mossy fiber-CA3 long-term potentiation by enhancing cAMP-specific phosphodiesterase 4 activity. Neuropsychopharmacology 35:1605-1617. CrossRef Medline

Chen JF, Huang Z, Ma J, Zhu J, Moratalla R, Standaert D, Moskowitz MA, Fink JS, Schwarzschild MA (1999) $A_{2 \mathrm{~A}}$ adenosine receptor deficiency attenuates brain injury induced by transient focal ischemia in mice. J Neurosci 19:9192-9200. Medline

Chen JF, Xu K, Petzer JP, Staal R, Xu YH, Beilstein M, Sonsalla PK, Castagnoli K, Castagnoli N Jr, Schwarzschild MA (2001) Neuroprotection by caffeine and $\mathrm{A}_{2 \mathrm{~A}}$ adenosine receptor inactivation in a model of Parkinson's disease. J Neurosci 21:RC143. Medline

Chen JF, Moratalla R, Yu L, Martín AB, Xu K, Bastia E, Hackett E, Alberti I, Schwarzschild MA (2003) Inactivation of adenosine $A_{2 A}$ receptors selectively attenuates amphetamine-induced behavioral sensitization. Neuropsychopharmacology 28:1086-1095. CrossRef Medline

Chen JF, Sonsalla PK, Pedata F, Melani A, Domenici MR, Popoli P, Geiger J, Lopes LV, de Mendonça A (2007) Adenosine $\mathrm{A}_{2 \mathrm{~A}}$ receptors and brain injury: broad spectrum of neuroprotection, multifaceted actions and "fine tuning" modulation. Prog Neurobiol 83:310-331. CrossRef Medline

Ciruela F, Escriche M, Burgueno J, Angulo E, Casadó V, Soloviev MM, Canela EI, Mallol J, Chan WY, Lluis C, McIlhinney RA, Franco R (2001) Metabotropic glutamate lalpha and adenosine $\mathrm{A}_{1}$ receptors assemble into functionally interacting complexes. J Biol Chem 276:18345-18351. CrossRef Medline

Ciruela F, Casadó V, Rodrigues RJ, Luján R, Burgueño J, Canals M, Borycz J, Rebola N, Goldberg SR, Mallol J, Cortés A, Canela EI, López-Giménez JF, Milligan G, Lluis C, Cunha RA, Ferré S, Franco R (2006) Presynaptic control of striatal glutamatergic neurotransmission by adenosine $A_{1}-A_{2 A}$ receptor heteromers. J Neurosci 26:2080-2087. CrossRef Medline

Correia-de-Sá P, Timóteo MA, Ribeiro JA (1996) Presynaptic A1 inhibitory/ A2A facilitatory adenosine receptor activation balance depends on motor nerve stimulation paradigm at the rat hemidiaphragm. J Neurophysiol 76:3910-3919. Medline

Corvol JC, Studler JM, Schonn JS, Girault JA, Hervé D (2001) G $\alpha_{\text {olf }}$ is necessary for coupling $D_{1}$ and $A_{2 a}$ receptors to adenylyl cyclase in the striatum. J Neurochem 76:1585-1588. CrossRef Medline

Cunha RA (2001a) Adenosine as a neuromodulator and as a homeostatic regulator in the nervous system: different roles, different sources and different receptors. Neurochem Int 38:107-125. CrossRef Medline

Cunha RA (2001b) Regulation of the ecto-nucleotidase pathway in rat hippocampal nerve terminals. Neurochem Res 26:979-991. CrossRef Medline

Cunha RA (2005) Neuroprotection by adenosine in the brain: from $A_{1}$ receptor activation to $\mathrm{A}_{2 \mathrm{~A}}$ receptor blockade. Purinergic Signal 1:111-134. CrossRef Medline

Cunha RA (2008) Different cellular sources and different roles of adenosine: $A_{1}$ receptor-mediated inhibition through astrocytic-driven volume transmission and synapse-restricted $\mathrm{A}_{2 \mathrm{~A}}$ receptor-mediated facilitation of plasticity. Neurochem Int 52:65-72. CrossRef Medline

Cunha RA, Correia-de-Sá P, Sebastião AM, Ribeiro JA (1996a) Preferential activation of excitatory adenosine receptors at rat hippocampal and neu- romuscular synapses by adenosine formed from released adenine nucleotides. Br J Pharmacol 119:253-260. CrossRef Medline

Cunha RA, Vizi ES, Ribeiro JA, Sebastião AM (1996b) Preferential release of ATP and its extracellular catabolism as a source of adenosine upon highbut not low-frequency stimulation of rat hippocampal slices. J Neurochem 67:2180-2187. Medline

Cunha RA, Brendel P, Zimmermann H, Ribeiro JA (2000) Immunologically distinct isoforms of ecto-5' ${ }^{\prime}$-nucleotidase in nerve terminals of different areas of the rat hippocampus. J Neurochem 74:334-338. CrossRef Medline

Deaglio S, Dwyer KM, Gao W, Friedman D, Usheva A, Erat A, Chen JF, Enjyoji K, Linden J, Oukka M, Kuchroo VK, Strom TB, Robson SC (2007) Adenosine generation catalyzed by CD39 and CD73 expressed on regulatory T cells mediates immune suppression. J Exp Med 204:12571265. CrossRef Medline

Di Virgilio F (2000) Dr. Jekyll/Mr. Hyde: the dual role of extracellular ATP. J Auton Nerv Syst 81:59-63. CrossRef Medline

Diógenes MJ, Neves-Tomé R, Fucile S, Martinello K, Scianni M, Theofilas P, Lopatár J, Ribeiro JA, Maggi L, Frenguelli BG, Limatola C, Boison D, Sebastião AM (2012) Homeostatic control of synaptic activity by endogenous adenosine is mediated by adenosine kinase. Cereb Cortex. Advance online publication. Retrieved May 22, 2013. doi:10.1093/cercor/bhs284. CrossRef Medline

Dunkley PR, Jarvie PE, Robinson PJ (2008) A rapid Percoll gradient procedure for preparation of synaptosomes. Nat Protoc 3:1718-1728. CrossRef Medline

Dunwiddie TV, Masino SA (2001) The role and regulation of adenosine in the central nervous system. Annu Rev Neurosci 24:31-55. CrossRef Medline

El-Tayeb A, Iqbal J, Behrenswerth A, Romio M, Schneider M, Zimmermann H, Schrader J, Müller CE (2009) Nucleoside-5' -monophosphates as prodrugs of adenosine $A_{2 \mathrm{~A}}$ receptor agonists activated by ecto- $5^{\prime}$ nucleotidase. J Med Chem 52:7669-7677. CrossRef Medline

El Yacoubi M, Ledent C, Parmentier M, Costentin J, Vaugeois JM (2008) Evidence for the involvement of the adenosine $\mathrm{A}_{2 \mathrm{~A}}$ receptor in the lowered susceptibility to pentylenetetrazol-induced seizures produced in mice by long-term treatment with caffeine. Neuropharmacology 55:3540. CrossRef Medline

Fastbom J, Pazos A, Palacios JM (1987) The distribution of adenosine $A_{1}$ receptors and $5^{\prime}$-nucleotidase in the brain of some commonly used experimental animals. Neuroscience 22:813-826. CrossRef Medline

Fausther M, Lecka J, Soliman E, Kauffenstein G, Pelletier J, Sheung N, Dranoff JA, Sévigny J (2012) Co-expression of ecto-5' -nucleotidase/CD73 with specific NTPDases differentially regulates adenosine formation in the rat liver. Am J Physiol Gastrointest Liver Physiol 302:G447-G459. CrossRef Medline

Flögel U, Burghoff S, van Lent PL, Temme S, Galbarz L, Ding Z, El-Tayeb A, Huels S, Bönner F, Borg N, Jacoby C, Müller CE, van den Berg WB, Schrader J (2012) Selective activation of adenosine $A_{2 A}$ receptors on immune cells by a CD73-dependent prodrug suppresses joint inflammation in experimental rheumatoid arthritis. Sci Transl Med 4:146ra108. CrossRef Medline

Fredholm BB, Chen JF, Cunha RA, Svenningsson P, Vaugeois JM (2005) Adenosine and brain function. Int Rev Neurobiol 63:191-270. CrossRef Medline

Frenguelli BG, Llaudet E, Dale N (2003) High-resolution real-time recording with microelectrode biosensors reveals novel aspects of adenosine release during hypoxia in rat hippocampal slices. J Neurochem 86:15061515. CrossRef Medline

Giménez-Llort L, Fernández-Teruel A, Escorihuela RM, Fredholm BB, Tobeña A, Pekny M, Johansson B (2002) Mice lacking the adenosine $A_{1}$ receptor are anxious and aggressive, but are normal learners with reduced muscle strength and survival rate. Eur J Neurosci 16:547-550. CrossRef Medline

Giménez-Llort L, Masino SA, Diao L, Fernández-Teruel A, Tobeña A, Halldner L, Fredholm BB (2005) Mice lacking the adenosine $A_{1}$ receptor have normal spatial learning and plasticity in the CA1 region of the hippocampus, but they habituate more slowly. Synapse 57:8-16. CrossRef Medline

Giménez-Llort L, Schiffmann SN, Shmidt T, Canela L, Camón L, Wassholm M, Canals M, Terasmaa A, Fernández-Teruel A, Tobeña A, Popova E, Ferré S, Agnati L, Ciruela F, Martínez E, Scheel-Kruger J, Lluis C, Franco R, Fuxe K, Bader M (2007) Working memory deficits in transgenic rats 
overexpressing human adenosine $\mathrm{A}_{2 \mathrm{~A}}$ receptors in the brain. Neurobiol Learn Mem 87:42-56. CrossRef Medline

Halassa MM, Florian C, Fellin T, Munoz JR, Lee SY, Abel T, Haydon PG, Frank MG (2009) Astrocytic modulation of sleep homeostasis and cognitive consequences of sleep loss. Neuron 61:213-219. CrossRef Medline

Hauber W, Münkle M (1997) Motor depressant effects mediated by dopamine $\mathrm{D} 2$ and adenosine $\mathrm{A}_{2 \mathrm{~A}}$ receptors in the nucleus accumbens and the caudate-putamen. Eur J Pharmacol 323:127-131. CrossRef Medline

Klyuch BP, Dale N, Wall MJ (2012) Deletion of ecto-5'-nucleotidase (CD73) reveals direct action potential-dependent adenosine release. J Neurosci 32:3842-3847. CrossRef Medline

Koszalka P, Ozüyaman B, Huo Y, Zernecke A, Flögel U, Braun N, Buchheiser A, Decking UK, Smith ML, Sévigny J, Gear A, Weber AA, Molojavyi A, Ding Z, Weber C, Ley K, Zimmermann H, Gödecke A, Schrader J (2004) Targeted disruption of cd73/ecto- $5^{\prime}$-nucleotidase alters thromboregulation and augments vascular inflammatory response. Circ Res 95:814821. CrossRef Medline

Kreutzberg GW, Barron KD, Schubert P (1978) Cytochemical localization of 5'-nucleotidase in glial plasma membranes. Brain Res 158:247-257. CrossRef Medline

Langer D, Hammer K, Koszalka P, Schrader J, Robson S, Zimmermann H (2008) Distribution of ectonucleotidases in the rodent brain revisited. Cell Tissue Res 334:199-217. CrossRef Medline

Larsson M, Sawada K, Morland C, Hiasa M, Ormel L, Moriyama Y, Gundersen V (2012) Functional and anatomical identification of a vesicular transporter mediating neuronal ATP release. Cereb Cortex 22:1203-1214. CrossRef Medline

Lee KS, Schubert P, Reddington M, Kreutzberg GW (1986) The distribution of adenosine $A_{1}$ receptors and $5^{\prime}$-nucleotidase in the hippocampal formation of several mammalian species. J Comp Neurol 246:427-434. CrossRef Medline

Lloyd HG, Lindström K, Fredholm BB (1993) Intracellular formation and release of adenosine from rat hippocampal slices evoked by electrical stimulation or energy depletion. Neurochem Int 23:173-185. CrossRef Medline

Lopes LV, Cunha RA, Kull B, Fredholm BB, Ribeiro JA (2002) Adenosine $\mathrm{A}_{2 \mathrm{~A}}$ receptor facilitation of hippocampal synaptic transmission is dependent on tonic $A_{1}$ receptor inhibition. Neuroscience 112:319-329. CrossRef Medline

Lovatt D, Xu Q, Liu W, Takano T, Smith NA, Schnermann J, Tieu K, Nedergaard M (2012) Neuronal adenosine release, and not astrocytic ATP release, mediates feedback inhibition of excitatory activity. Proc Natl Acad Sci U S A 109:6265-6270. CrossRef Medline

Martire A, Tebano MT, Chiodi V, Ferreira SG, Cunha RA, Köfalvi A, Popoli P (2011) Pre-synaptic adenosine $A_{2 A}$ receptors control cannabinoid CB1 receptor-mediated inhibition of striatal glutamatergic neurotransmission. J Neurochem 116:273-280. CrossRef Medline

Matos M, Augusto E, Santos-Rodrigues AD, Schwarzschild MA, Chen JF, Cunha RA, Agostinho P (2012a) Adenosine $A_{2 A}$ receptors modulate glutamate uptake in cultured astrocytes and gliosomes. Glia 60:702-716. CrossRef Medline

Matos M, Augusto E, Machado NJ, dos Santos-Rodrigues A, Cunha RA, Agostinho P (2012b) Astrocytic adenosine $A_{2 A}$ receptors control the amyloid- $\beta$ peptide-induced decrease of glutamate uptake. J Alzheimers Dis 31:555-567. CrossRef Medline

Nagel J, Schladebach H, Koch M, Schwienbacher I, Müller CE, Hauber W (2003) Effects of an adenosine $A_{2 A}$ receptor blockade in the nucleus accumbens on locomotion, feeding, and prepulse inhibition in rats. Synapse 49:279-286. CrossRef Medline

Nam HW, Hinton DJ, Kang NY, Kim T, Lee MR, Oliveros A, Adams C, Ruby CL, Choi DS (2013) Adenosine transporter ENT1 regulates the acquisition of goal-directed behavior and ethanol drinking through $\mathrm{A}_{2 \mathrm{~A}}$ receptor in the dorsomedial striatum. J Neurosci 33:4329-4338. CrossRef Medline

Napieralski R, Kempkes B, Gutensohn W (2003) Evidence for coordinated induction and repression of ecto-5'-nucleotidase (CD73) and the $A_{2 a}$ adenosine receptor in a human B cell line. Biol Chem 384:483-487. CrossRef Medline

Pankratov Y, Lalo U, Verkhratsky A, North RA (2006) Vesicular release of ATP at central synapses. Eur J Physiol 452:589-597. CrossRef

Parkinson FE, Damaraju VL, Graham K, Yao SY, Baldwin SA, Cass CE, Young JD (2011) Molecular biology of nucleoside transporters and their distri- butions and functions in the brain. Curr Top Med Chem 11:948-972. CrossRef Medline

Pascual O, Casper KB, Kubera C, Zhang J, Revilla-Sanchez R, Sul JY, Takano H, Moss SJ, McCarthy K, Haydon PG (2005) Astrocytic purinergic signaling coordinates synaptic networks. Science 310:113-116. CrossRef Medline

Peng Z, Fernandez P, Wilder T, Yee H, Chiriboga L, Chan ES, Cronstein BN (2008) Ecto-5' -nucleotidase (CD73)-mediated extracellular adenosine production plays a critical role in hepatic fibrosis. FASEB J 22:2263-2272. CrossRef Medline

Phillips GR, Huang JK, Wang Y, Tanaka H, Shapiro L, Zhang W, Shan WS, Arndt K, Frank M, Gordon RE, Gawinowicz MA, Zhao Y, Colman DR (2001) The presynaptic particle web: ultrastructure, composition, dissolution, and reconstitution. Neuron 32:63-77. CrossRef Medline

Pinto-Duarte A, Coelho JE, Cunha RA, Ribeiro JA, Sebastião AM (2005) Adenosine $\mathrm{A}_{2 \mathrm{~A}}$ receptors control the extracellular levels of adenosine through modulation of nucleoside transporters activity in the rat hippocampus. J Neurochem 93:595-604. CrossRef Medline

Rebola N, Pinheiro PC, Oliveira CR, Malva JO, Cunha RA (2003) Subcellular localization of adenosine $A_{1}$ receptors in nerve terminals and synapses of the rat hippocampus. Brain Res 987:49-58. CrossRef Medline

Rebola N, Canas PM, Oliveira CR, Cunha RA (2005) Different synaptic and subsynaptic localization of adenosine $\mathrm{A}_{2 \mathrm{~A}}$ receptors in the hippocampus and striatum of the rat. Neuroscience 132:893-903. CrossRef Medline

Rebola N, Lujan R, Cunha RA, Mulle C (2008) Adenosine $\mathrm{A}_{2 \mathrm{~A}}$ receptors are essential for long-term potentiation of NMDA-EPSCs at hippocampal mossy fiber synapses. Neuron 57:121-134. CrossRef Medline

Rodrigues RJ, Alfaro TM, Rebola N, Oliveira CR, Cunha RA (2005) Colocalization and functional interaction between adenosine $A_{2 A}$ and metabotropic group 5 receptors in glutamatergic nerve terminals of the rat striatum. J Neurochem 92:433-441. CrossRef Medline

Rosin DL, Hettinger BD, Lee A, Linden J (2003) Anatomy of adenosine $A_{2 A}$ receptors in brain: morphological substrates for integration of striatal function. Neurology 61:S12-S18. Medline

Schiffmann SN, Libert F, Vassart G, Vanderhaeghen JJ (1991) Distribution of adenosine $\mathrm{A}_{2}$ receptor mRNA in the human brain. Neurosci Lett 130: 177-181. CrossRef Medline

Schmitt LI, Sims RE, Dale N, Haydon PG (2012) Wakefulness affects synaptic and network activity by increasing extracellular astrocyte-derived adenosine. J Neurosci 32:4417-4425. CrossRef Medline

Schoen SW, Kreutzberg GW (1997) 5'-nucleotidase enzyme cytochemistry as a tool for revealing activated glial cells and malleable synapses in CNS development and regeneration. Brain Res Brain Res Protoc 1:33-43. CrossRef Medline

Shen HY, Coelho JE, Ohtsuka N, Canas PM, Day YJ, Huang QY, Rebola N, Yu L, Boison D, Cunha RA, Linden J, Tsien JZ, Chen JF (2008) A critical role of the adenosine $\mathrm{A} 2 \mathrm{~A}$ receptor in extrastriatal neurons in modulating psychomotor activity as revealed by opposite phenotypes of striatum and forebrain A2A receptor knock-outs. J Neurosci 28:2970-2975. CrossRef Medline

Singer P, McGarrity S, Shen HY, Boison D, Yee BK (2012) Working memory and the homeostatic control of brain adenosine by adenosine kinase. Neuroscience 213:81-92. CrossRef Medline

Sowa NA, Taylor-Blake B, Zylka MJ (2010) Ecto-5'-nucleotidase (CD73) inhibits nociception by hydrolyzing AMP to adenosine in nociceptive circuits. J Neurosci 30:2235-2244. CrossRef Medline

Svenningsson P, Lindskog M, Rognoni F, Fredholm BB, Greengard P, Fisone G (1998) Activation of adenosine $A_{2 A}$ and dopamine $D_{1}$ receptors stimulates cyclic AMP-dependent phosphorylation of DARPP-32 in distinct populations of striatal projection neurons. Neuroscience 84:223-228. CrossRef Medline

Thompson LF, Eltzschig HK, Ibla JC, Van De Wiele CJ, Resta R, MoroteGarcia JC, Colgan SP (2004) Crucial role for ecto-5'-nucleotidase (CD73) in vascular leakage during hypoxia. J Exp Med 200:1395-1405. CrossRef Medline

Thomson S, Bao D, Deng A, Vallon V (2000) Adenosine formed by $5^{\prime}$ nucleotidase mediates tubuloglomerular feedback. J Clin Invest 106:289298. CrossRef Medline

Trifilieff P, Rives ML, Urizar E, Piskorowski RA, Vishwasrao HD, Castrillon J, Schmauss C, Slättman M, Gullberg M, Javitch JA (2011) Detection of antigen interactions ex vivo by proximity ligation assay: endogenous do- 
pamine $\mathrm{D}_{2}$-adenosine $\mathrm{A}_{2 \mathrm{~A}}$ receptor complexes in the striatum. Biotechniques 51:111-118. CrossRef Medline

Wei CJ, Singer P, Coelho J, Boison D, Feldon J, Yee BK, Chen JF (2011) Selective inactivation of adenosine $\mathrm{A}_{2 \mathrm{~A}}$ receptors in striatal neurons enhances working memory and reversal learning. Learn Mem 18:459-474. CrossRef Medline

Wieraszko A, Goldsmith G, Seyfried TN (1989) Stimulation-dependent release of adenosine triphosphate from hippocampal slices. Brain Res 485: 244-250. CrossRef Medline

Yu L, Shen HY, Coelho JE, Araújo IM, Huang QY, Day YJ, Rebola N, Canas PM, Rapp EK, Ferrara J, Taylor D, Müller CE, Linden J, Cunha RA, Chen JF (2008) Adenosine $A_{2 A}$ receptor antagonists exert motor and neuroprotective effects by distinct cellular mechanisms. Ann Neurol 63: 338-346. CrossRef Medline

Zernecke A, Bidzhekov K, Ozüyaman B, Fraemohs L, Liehn EA, Lüscher-
Firzlaff JM, Lüscher B, Schrader J, Weber C (2006) CD73/ecto-5'nucleotidase protects against vascular inflammation and neointima formation. Circulation 113:2120-2127. CrossRef Medline

Zhang D, Xiong W, Chu S, Sun C, Albensi BC, Parkinson FE (2012) Inhibition of hippocampal synaptic activity by ATP, hypoxia or oxygen-glucose deprivation does not require CD73. PLoS One 7:e39772. CrossRef Medline

Zhou SJ, Zhu ME, Shu D, Du XP, Song XH, Wang XT, Zheng RY, Cai XH, Chen JF, He JC (2009) Preferential enhancement of working memory in mice lacking adenosine $\mathrm{A}_{2 \mathrm{~A}}$ receptors. Brain Res 1303:74-83. CrossRef Medline

Zylka MJ, Sowa NA, Taylor-Blake B, Twomey MA, Herrala A, Voikar V, Vihko P (2008) Prostatic acid phosphatase is an ectonucleotidase and suppresses pain by generating adenosine. Neuron 60:111-122. CrossRef Medline 